
A
$\mathbf{R}$
$\mathrm{T}$
Y
K
$\mathrm{U}$
$\mathbf{E}$
$\mathbf{Y}$

Zeszyty Prawnicze

$20.1 / 2020$, s. 7-44

DOI 10.21697/zp.2020.20.1.01

\title{
Aneta Skalec
}

Uniwersytet Humanistyczno-Przyrodniczy im. Jana Długosza w Częstochowie

\section{ODPOWIEDZIALNOŚĆ ZA SZKODY WYRZĄDZONE PRZEZ ZWIERZETTA W UPRAWACH W EGIPCIE PTOLEMEJSKIM}

W starożytnym Egipcie problem szkód wyrządzanych przez zwierzęta w uprawach musiał być istotny, odwieczny i drażniący', bowiem uprawa roli i chów bydła były tam prowadzone obok siebie 2 . Z okresu ptolemejskiego pochodzi z Egiptu stosunkowo duża liczba dokumentów papirusowych ${ }^{3}$ poświadczających szeroką skalę tego rodzaju strat.

1 N. Lewis, Life in Egypt under Roman Ruler, Oxford 1983, s. 121. O hodowli zwierząt w okresie ptolemejskim por. C. PRÉAUX, L'économie royale des Lagides, Bruxelles 1939, s. 213-225, 228; M. SCHNEBEL, Die Landwirtschaft im hellenistischen Ägypten, München 1925, s. 323-328.

2 J.G. KeEnan, Pastoralism in Roman Egypt, «The Bulletin of the American Society of Papyrologists» 26/1989, s. 191.

3 Papirusy przywoływane są przy użyciu powszechnie przyjętych skrótów za: CHECKLIST OF EDITIONS OF GREEK, LATIN, DEMOTIC AND COPTIC PAPYRI, OSTRACA AND TABLETS, z podaniem tomu (duża cyfra rzymska), następnie numeru samego papirusu (cyfra arabska), kolumny, jeśli dokument był na nie podzielony (mała cyfra rzymska), ewentualnie skrótów $r$ (recto) lub $v$ (verso) i linii (również cyfra arabska). Ponadto przy pierwszym cytowaniu dokumentu w nawiasach podawane są data oraz miejscowość, z której pochodzi papirus [np. P. Hels. I 31, 24-26 (160 p.n.e., nom herakleopolitański)]. Jeśli są one nieznane, w ich miejsce stawiany jest znak zapytania. W przypadku papirusów opublikowanych kilkukrotnie, przy pierwszym cytowaniu podawane są wszystkie sigle publikacji, natomiast w kolejnych jedynie pierwsza z nich. Wszystkie tłumaczenia papirusów są tłumaczeniami własnymi autorki. 
Są to przede wszystkim petycje ${ }^{4}$. Część z nich dotyczyła bezpośrednio przypadku zniszczeń wywoływanych przez zwierzęta w cudzych uprawach, część natomiast donosiła o tego rodzaju wydarzeniach przy okazji innych skarg, przede wszystkim związanych z pobiciem ${ }^{5}$. Poza tym pewne informacje znajdujemy w listach ${ }^{6}$. Tego rodzaju naruszenia były również przedmiotem ustawodawstwa ptolemejskiego oraz innych dokumentów wydawanych przez administrację państwową ${ }^{7}$. Ich łączna liczba jest duża, co pozwala na w miarę pewne odtworzenie okoliczności, w których dochodziło do sporu, ale jeżeli chodzi już o zakres odpowiedzialności, to nie wszystkie kwestie z nim związane są w pełni jasne.

Punktem wyjścia do wyrządzenia szkody na sąsiednim terenie był zawsze fakt, że obce zwierzęta weszły na cudzy grunt, wypasając się tam następnie (ewentualnie były przepędzane, zadeptując uprawy, ale takie przypadki poświadczone są tylko w okresie rzymskim) ${ }^{8}$.

Jeżeli chodzi o sposoby powodowania zniszczeń, to Rafał Taubenschlag, który jako pierwszy zajął się papirologicznie poświadczonymi przypadkami szkód wyrządzonych przez zwierzęta w uprawach, wskazywał na istnienie w Egipcie ptolemejsko-rzymskim skarg analogicznych do rzymskich actio de pastu oraz de pauperie ${ }^{9}$. Autor zdaje się

$4 \quad$ P. Köln III 140 (244-242/219-217 p.n.e., nom arsinoicki); P. Enteux. 75=P. Lille II 6 i 38 (222 p.n.e., Magdola); P. Enteux. 65 (221 p.n.e., Magdola); P. Petr. III 32 (g) recto (b)=P. Lond. III 570 descr.=P. Petr. II 32 (2 b) (217 p.n.e., Sebennytos); P. Heid. VII 394 (214 p.n.e., Moithymis); P. Hels. I 31 (160 p.n.e., nom herakleopolitański); P. Heid. IX 422 (158 p.n.e., Tinteris); BGU VI 1251 (155 lub 144 p.n.e., Filadelfia); BGU VIII 1831 (51/50 p.n.e., nom herakleopolitański); P. Ryl. II 69=C. Pap. Hengstl 47 (34 p.n.e., Euhemeria?); P. Wash. Univ. II 77=P. Vind. Worp 2 (21 p.n.e., nom oksyrynchicki).

5 Por. o tym poniżej.

$6 \quad$ PSI IV 372 (250 p.n.e., Filadelfia); P. Cair. Zen. IV 59631 (poł. III w. p.n.e., Filadelfia).

$7 \quad$ P. Petr. III 26 (III w. p,n.e., nom arsinoicki); P. Tebt. I 27=W. Chr. 331 (114 p.n.e., Tebtynis).

${ }^{8}$ SB XX 14632 (39-40 n.e., nom arsinoicki?); P. Mich. V 229 (48 n.e., Talei); PSI IX 1057 (32 n.e., Euhemeria); P. Cair. Masp. I 67087 (543 n.e., Afrodito).

9 R. Taubenschlag, Die 'Actio de pastu, de pauperie' und 'de arboribus caesis' im Rechte der Papyri, "Archív Orientální» 20/1952, s. 65-68 = R. TAubenschlag, 'Opera Minora', II, Warszawa 1959, s. 567-571. Actio de pauperie doczekała się bogatej bibliografii. Jej dokładny wykaz znajduje się w artykule M. PoloJac, 'Actio de pauperie’: 
nie zauważać faktu, że pierwsza z nich dotyczyła w prawie rzymskim szkód wyrządzonych na skutek nielegalnego wypasu, którego dopuścili się pasterze zwierząt, natomiast druga - zniszczeń wywołanych przez stworzenia samodzielnie, zasadniczo jednak nie w uprawach. Dotyczyła ona bowiem jedynie szkód powodowanych przez zwierzęta z własnej inicjatywy i contra naturam. Wypasanie się zwierząt jak najbardziej leżało natomiast $\mathrm{w}$ ich naturze ${ }^{10}$.

anthropomorphism and rationalism, «Fundamina» 18.2/2012 (http://reference.sabinet. co.za/webx/access/electronic_journals/funda/funda_v18_n2_a8.pdf), s.120,przyp. 4 (dostęp: 31 lipca 2019 r.). Wśród prac warto wymienić: F. Haymann, Textkritische Studien zum römischen Obligationenrecht, III: Zur Haftung von Tierschaden ('actio de pauperie'), «ZSS» 42/1921, s. 357-393; J. KeRR Wylie, 'Actio de pauperie', [w:] Studi in onore di Salvatore Riccobono, IV, red. S. Riccobono, G. Bavier A, Palermo 1936, s. 459-521; D.I.C. Ashton-Cross, Liability in Roman law for damage caused by animals, "Cambridge Law Journal» 11/1953, s. 395-403; D.I.C. Ashton-Cross, Liability for animals in Roman law, «Cambridge Law Journal»17.2/1959, s. 189-192; R. HAAsE, Die Behandlung von Tierschäden in den Keilschriftrechten, «RIDA»14/1967, s. 11-65; A. WATson, The original meaning of 'pauperies', «RIDA»17/1970, s. 357-367; B.S. JACKsON, Liability for animals in Roman law: an historical sketch, "Cambridge Law Journal» 37.1/1978, s. 122 -143; H. Ankum, 'Actio de pauperie et actio legis Aquiliae' dans le droit romain classique, [w:] Studi in onore di Cesare Sanfilippo, II, Milano 1982, s. 13-59; T. Honoré, Liability for animals: Ulpian and the compilers, [w:] Satura Roberto Feenstra: sexagesimum quintum annum aetatis complenti ab alumnis collegis amicis oblata, red. R. FEENSTRA, J.A. Ankum, J.E. Spruit, Fribourg 1985, s. 239-250; M.V. GiAngrieco Pessi, Ricerche sull' actio de pauperie' dalle XII Tavole ad Ulpiano, Napoli 1995; J. MÉLÈze ModrzEJEWski, Ulpien et la nature des animaux, [w:] Droit impérial et traditions locales dans l'Égypte romaine, Aldershot 1990, s. 177-199; IDEM, Hommes libres et bêtes dans les droits antiques, [w:] Statut personnel et liens de famille dans les droits de l'Antiquité, Aldershot 1993, s. 83-84; M. PoloJAC, L'actio de pauperie' ed altri mezzi processuali nel caso di danneggiamento provocato dall'animale nel diritto romano, «Ius Antiquum» 8/2001, s. 83-89, http://www.dirittoestoria.it/iusantiquum/articles/N8Polojac.htm\#_ftn2 (dostęp: 31 lipca 2019 r.); M. Polojac, 'Actio de Pauperie' and Liability for Damage Caused by Animals in Roman Law, Belgrade 2003; M. Polojac, 'Actio de pauperie': anthropomorphism..., s. 119-144. O actio de pastu por. przede wszystkim A. FLINIAUx, Une vieille action du droit romain: l'actio de pastu', [w:] Mélanges de droit romain dédiés à Georges Cornil, I, red. P. Collinet, F. DE Visscher, Paris 1926, s. 245-294.

10 M. Polojac, L'actio de pauperie' ed altri mezzi..., s. 83-89. 
Pierwszy przypadek celowego wpuszczania zwierząt na sąsiednie tereny Taubenschlag ${ }^{11}$ identyfikował $\mathrm{z}$ zastosowaniem w petycjach sfor-

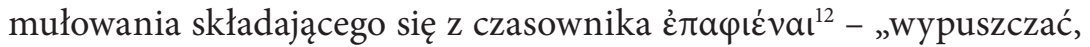
wpuszczać, pozwalać się paść" oraz jednego z terminów określających spasanie czy wypasanie $e^{13}$.

Znajdujemy jednak papirusy, w których poświadczone są sformułowania zdające się sugerować, że to owce, bydło czy inne stworzenia same weszły na sąsiednie tereny i wypasając się tam, wyrządziły szkody ${ }^{14}$. Składały

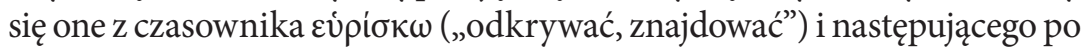
nim jednego z wymienionych powyżej terminów na określenie wypasania czy spasania, a więc „znalazłem zwierzęta, które się pasły”'15. Dokumenty

\footnotetext{
11 R. Taubenschlag, Die 'Actio de pastu'..., s. 567-570.

12 P. Köln III 140, 11-13; P. Enteux. 65, 9-8; BGU VI 1251, 10-12, 15-16; P. Wash.
} Univ. II 77, 9-14; BGU VI 1251, 10-12. Jako przykład może posłużyć tutaj $P$. Köln III 140:

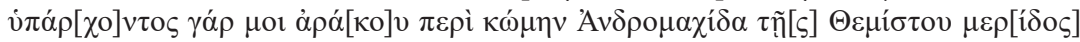

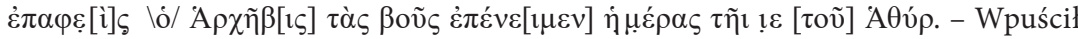
bowiem Harchebis na należące do mnie pole lędźwianu w pobliżu wsi Andromachis w meris Themistosa krowy, wypasając je 15. dnia miesiąca Hathyr.

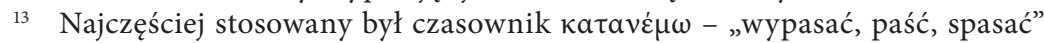
(P. Cair. Zen. IV 59631, 7; P. Petr. III 26, 7; P. Petr. III 32 (g) recto (b), 4; P. Heid. VII 394, 6; BGU VI 1251, 15; P. Heid. IX 422, 17; BGU VIII 1831, 11-12; P. Ryl. II 69, 11; P. Wash. Univ. II 77, 11). Poza nim znajdujemy w dokumentach także inne terminy, którymi

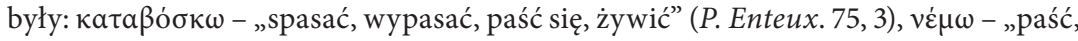
gnać, pędzić na pastwisko” (P. Cair. Zen. IV 59631, 9), દ̇đıvé $\mu \omega$ - „paść (bydło) na cu-

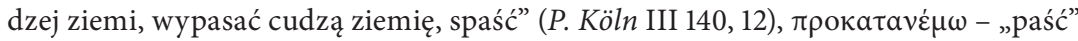
(P. Heid. IX 422, 18-19). Przy okazji wypasu albo też przepędzania zwierząt szkody

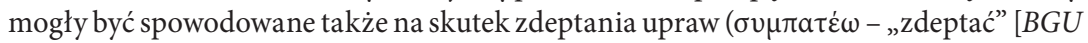
VI 1251, 15-16; P. Wash. Univ. II 77, 11-12]). Poza nimi w petycjach występują niekiedy czasowniki w sposób ogólny wskazujące na wyrządzenie szkody, bez dokładniejszego

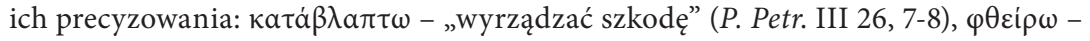
„niszczyć” (P. Enteux. 65, 9-10; P. Petr. III 32 (g) recto (b), 8).

14 P. Cair. Zen. IV 59631; P. Petr. III 32 (g) recto (b); P. Enteux. 75; P. Heid. VII 394; P. Heid. IX 422; P. Hals. I 31 (ten nie jest całkowicie pewien ze względu na jego fragmentaryczność).

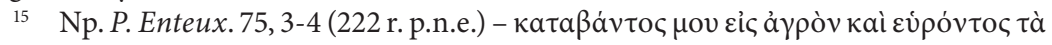

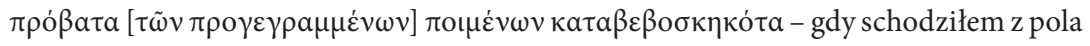
i odkryłem owce wspomnianych powyżej pasterzy, które wypasały się na pastwisku na jednej z działek. 
te zawierały zatem informacje o wykryciu zwierzą wypasających się na cudzym terenie, bez wyraźnego wskazania na udział czy inicjatywę ze strony ich właścicieli lub pasterzy. Ich imiona były jednak wymieniane w petycjach, co mogło oznaczać, że albo brali oni udział we wprowadzeniu zwierząt na cudze pola, albo też ich określenie mogło służyć jedynie wskazaniu osób, które należało pociągnąć do odpowiedzialności. W tym drugim przypadku mielibyśmy do czynienia ze szkodami, które nie zostały spowodowane na skutek czynnego działania ich właścicieli czy pasterzy, ale samych zwierząt. Na pierwszą z możliwości może jednak wskazywać fakt, że w części tych dokumentów znajdujemy informację o zatrzymaniu pasterzy lub dopuszczeniu się przez nich pobicia, co sugerowałoby ich obecność podczas wypasu, a co zatem idzie, najprawdopodobniej także ich bezpośrednią odpowiedzialność za zajście ${ }^{16}$.

Stosowanie różnorodnych sformułowań w papirusach nie może być zatem $\mathrm{z}$ całkowitą pewnością traktowane jako kryterium decydujące o odmiennym sposobie wyrządzenia szkody, chociaż oczywiście, zróżnicowanie sposobów wyrządzania strat jest naturalne. Zniszczenia mogły być wyrządzane przez zwierzęta w cudzych uprawach w dwojaki sposób - albo same wchodziły one na cudzy grunt, albo też były tam świadomie wprowadzane czy puszczane przez pasterzy. Nie usprawiedliwia to jednak od razu wyciągania wniosku, jak to uczynił Taubenschlag, że różnorodność okoliczności mogących prowadzić do powstawania szkód pociągała za sobą w Egipcie zastosowanie odmiennych skarg, którym odpowiadałoby zastosowanie w petycjach zróżnicowanych sformułowań ${ }^{17}$. W źródłach papirusowych to rozgraniczenie nie jest bowiem wcale wyraźne, a jego dokonanie przez polskiego papirologa jest raczej wynikiem nakładania czysto romanistycznej siatki pojęć na rzeczywistość Egiptu ptolemejsko-rzymskiego i poszukiwania w dokumentach papirusowych instytucji analogicznych do tych znanych z prawa rzymskiego (actio de pastu, actio de pauperie). Stosowanie tej romanistycznej terminologii jest tym bardziej nieuzasadnione w odniesieniu do

Podobne klauzule znajdujemy w następujących dokumentach: P. Petr. III 32 (g) recto (b), 3-5; P. Hels. I 31, 12-15; P. Heid. IX 422, 9-17.

16 P. Enteux. 75; P. Hels. I 31; P. Heid. IX 422.

17 R. Taubenschlag, Die 'Actio de pastu'..., s. 567-569. 
dokumentów z czasów panowania Lagidów, kiedy prawo rzymskie nie mogło i nie miało wpływu na prawo obowiązujące w Egipcie. Warto zatem przyjrzeć się dokładniej dokumentom ptolemejskim pod kontem wynikającego z nich charakteru odpowiedzialności.

Właściciel czy dzierżawca zniszczonych upraw, który znalazł na swoim terenie cudze zwierzęta, przystępował do ich wygnania lub usunięcia, zanim wyrządziły dalsze szkody, przy czym powinny być one wydane przez niego urzędnikom policyjnym ${ }^{18}$, jako corpora delicti. Taka sytuacja poświadczona jest w kilku dokumentach, z których wynika, że tego rodzaju działania często kończyły się bójkami ${ }^{19}$.

Poszkodowany występował następnie przeciwko pasterzowi czy pasterzom z petycją, kierując ją do różnych osób, będących zasadniczo typowymi adresatami skarg, którymi w czasach ptolemejskich byli król ${ }^{20}$,

18 A.E.R. Boak, H.C. Youtie, P. Cair. Isid., s. 305.

19 O takim zajściu znajdujemy wzmiankę w P. Petr. III 32 (g) recto (b), w którym Kroton zatrzymał zwierzęta w celu doprowadzenia ich do strażników. Zanim zdążył to zrobić, został jednak napadnięty przez Kallifona, który uwolnił stado,

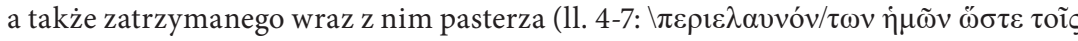

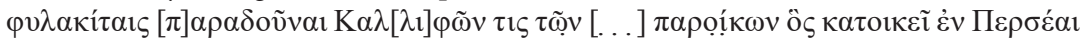

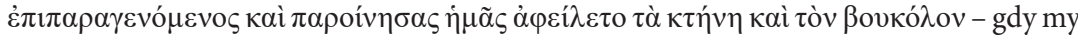
odciągnęliśmy (je) w celu wydania strażnikom, pewien Kallifon mieszkający w Persea, przybywszy źle nas potraktował, i uwolnił stado i pasterza). Tak samo przedstawiała się sytuacja w P. Heid. IX 422, z którego wyraźnie wynika, że poszkodowany chciał przekazać owce strażnikom, ale zanim zdołał to zrobić, został pobity przez pasterzy

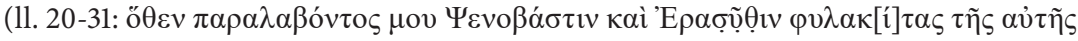

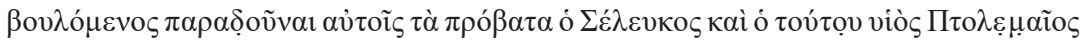

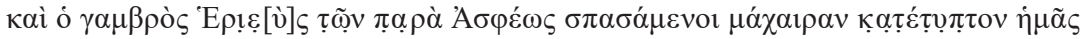

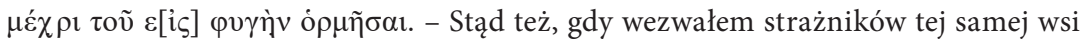
Psenobastisa i Erasythisa, żeby wydać im owce, Seleukos i jego syn Ptolemaios i zięć Herieus, ludzie od Asfeusa, wyciągnęli duży miecz, aż rzuciliśmy się do ucieczki).

20 P. Enteux. 75; P. Enteux. 65. W obydwu dokumentach poszkodowany prosił, aby król napisał do stratega, który ze swojej strony miał rozkazać epistatesowi, aby ten przysłał sprawców przed szefa nomu. 


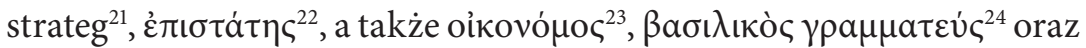
à $\rho \chi\left\llcorner\varphi \nu \lambda \alpha \kappa i \tau \eta \varsigma^{25}\right.$.

Dysponujemy kilkoma petycjami, które wskazują także na innych niż adresaci skarg urzędników zaangażowanych w rozwiązywanie problemów związanych ze szkodami wyrządzanymi przez zwierzęta. Byli nimi przede wszystkim niżsi funkcjonariusze policyjni, a więc za panowania

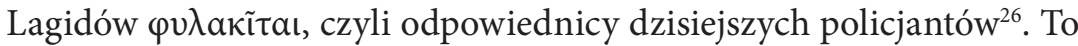
im poszkodowani rolnicy przekazywali zwierzęta zatrzymane podczas

\footnotetext{
$21 \quad B G U$ VIII 1831.

22 P. Köln III 140 - epistates meris Themistesa; BGUVI 1251 - epistates wsi Filadelfia.

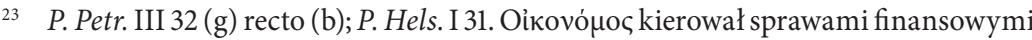
nomu. Jego główne obowiązki koncentrowały się na ziemi, jej maksymalnym prawidłowym wykorzystaniu, zbieraniu podatków i nadzorowaniu handlu (D. PAPADopoulou, The administration of Egypt in Hellenistic times. The rise and fall of the oikonomos, «Anistorion Journal»12/2010, s. 1-4). Oikonomos rozpatrywał również skargi rolników w sprawach wchodzących w zakres jego kompetencji. Ponadto, jako wpływowy człowiek mógł nieformalnie rozstrzygać spory normalnie podlegające kompetencjom innych urzędników. A.E. SAMueL, The judicial competence of the oikonomos in the III century B.C., [w:] Atti dell'XI Congresso Internazionale di Papirologia, Milano, 2-8 settembre 1965, Milano 1966, s. 444-450. Skierowanie do niego dwóch wyliczonych powyżej petycji wynikało najprawdopodobniej z faktu, że szkody dotknęły ziemi królewskiej, co wyraźnie poświadczone jest w P. Hels. I 31.

${ }^{24}$ P. Heid. IX 422. Jego rola w tym dokumencie ograniczona była jedynie do przekazania kopii petycji strategowi, z prośbą, ażeby ten wezwał przed siebie sprawców. Był to urzędnik nomu występujący w dokumentach papirusowych od połowy III w. p.n.e. do końca czasów ptolemejskich. Funkcjonował on także w czasach rzymskich, ale jego urząd zmienił wówczas nieco swój charakter. O urzędniku tym por. J.F. OATEs, The Ptolemaic Basilikos Grammateus (BASP Supplements 8), Atlanta 1995; C. Armoni, Studien zur Verwaltung des Ptolemäischen Ägypten: Das Amt des Basilikos Grammateus, Paderborn 2012.

25 P. Heid. VII 394. Był on urzędnikiem pełniącym m.in. funkcje policyjne, takie jak aresztowanie i transportowanie więźniów. Otrzymywał on także petycje od mieszkańców wsi, zazwyczaj dotyczące kradzieży, przemocy czy szkód. O tym urzędniku por. dokładniej J. Bauschatz, Law and Enforcement in Ptolemaic Egypt, Cambridge 2013, s. 68-78.

26 Do ich zadań należało m.in. aresztowanie przestępców, transportowanie więźniów, badanie przestępstw, otrzymywanie petycji i sporządzanie raportów. W ramach prowadzonych śledztw mogli oni odwiedzać sceny przestępstwa, badać dowody, szkody

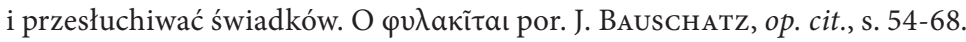


nielegalnego wypasu ${ }^{27}$, a oni ze swojej strony przybywali na zniszczone tereny, gdzie okazywane były im szkody, co służyło ich potwierdzeniu i oszacowaniu ${ }^{28}$.

Oczywistym skutkiem wejścia zwierząt na cudzy teren było zniszczenie przez nie upraw, w związku z czym naturalnym elementem petycji przedkładanych przez poszkodowanych właścicieli czy dzierżawców było wskazanie wysokości poniesionych strat ${ }^{29}$.

Najważniejszym dokumentem z okresu ptolemejskiego dotyczącym szkód wyrządzanych w uprawach przez zwierzęta, dostarczającym informacji o odpowiedzialności istniejącej w tego rodzaju przypadkach, jest P. Petr. III 26 - ustawa królewska, będąca najprawdopodobniej wy-

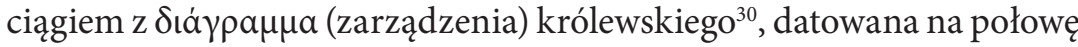
III w. p.n.e. ${ }^{31}$ Zawierała ona zbiór regulacji prawnych, w tym w liniach

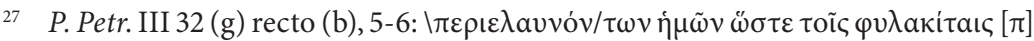

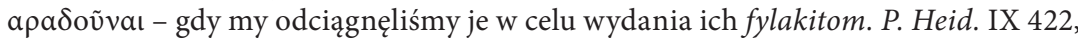

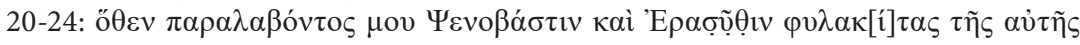

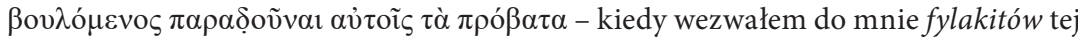
samej (wsi), Psenobastina i Erasythisa.

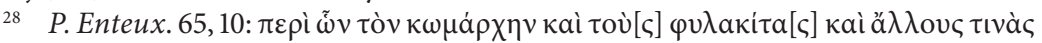

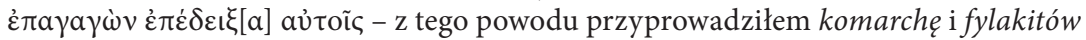
i inne osoby, żeby pokazać im.

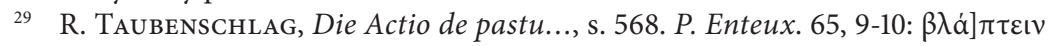

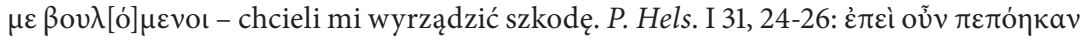

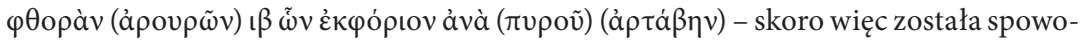
dowana strata 12 arur, z których podatek wynosi jedną artabę pszenicy. BGU VI 1251,

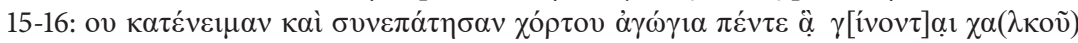

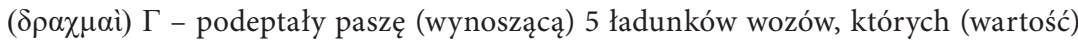
wynosi 3000 srebrnych drachm. P. Heid. VII 394, 13-14: oṽ $\tau 1 \mu \tilde{\omega} \mu \alpha 1$ ( $\delta \rho \alpha \chi \mu \tilde{\omega} v) v$-które

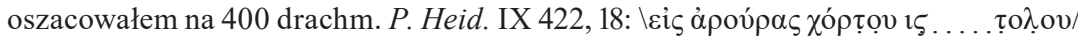

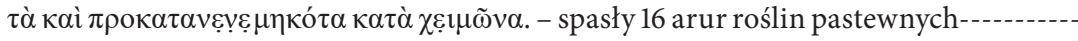

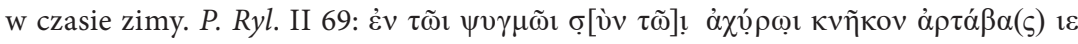

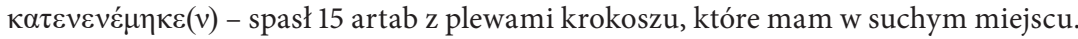

30 J. MÉLÈze Modrzejewski, Ulpien et la nature..., s. 192.

31 Wskazywane jest, że jego wydanie przypada albo na ostatnie lata panowania Ptolemeusza III Euergetesa (M.-Th. Lenger, Le fragment de loi ptolémaïque P. Petrie III 26 (Bodl. Ms. Gr. class. d. 27 [P]), [w:] Studi in onore di Ugo Enrico Paoli, Firenze 1956, s. 463), albo na pierwsze lata panowania Ptolemeusza II Filadelfosa (ok. 240 r. p.n.e.). J. MÉLÈZE ModrZEJEWski, Ulpien et la nature..., s. 192. 
6-16 postanowienia dotyczące szkód wyrządzonych przez zwierzęta. Jej tekst brzmi następująco:

$\dot{\varepsilon} \grave{\alpha} v \dot{\varepsilon} \mu \beta \tilde{\eta} \iota$ ßoṽ

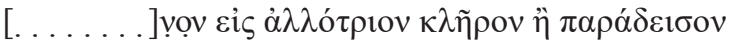

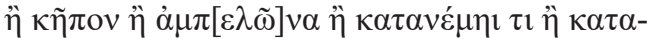

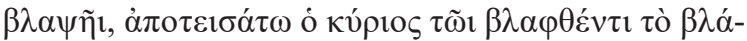

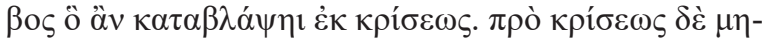

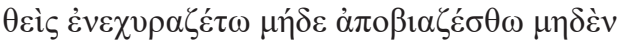

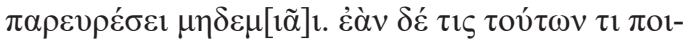

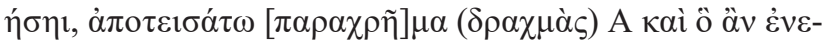

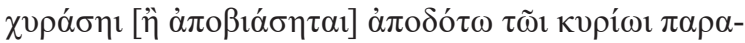

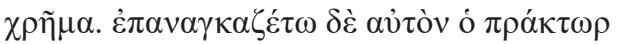

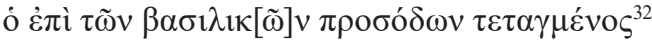

Jeśli bydło lub zwierzę pociągowe lub owca lub jakieś inne

-- wejdzie na cudzy kleros albo do sadu albo ogrodu albo winnicy, czy to będzie paść się, czy to wyrządzi szkodę, pan niech zgodnie z wyrokiem zapłaci poszkodowanemu szkodę, którą (zwierzę) wyrządziło. Przed wyrokiem zaś nikt niech nie zawładnie, ani nie używa przemocy pod żadnym pretekstem. Jeśli zaś ktoś zrobi coś z tych rzeczy, niech zapłaci $1000 \mathrm{drachm}$ i da panu (zwierzęcia) to, co zajął albo [zabrał siłą]. Poborca podatków królewskich niech zmusi go [do zapłaty].

W zarządzeniu tym uregulowany został przypadek szkód wyrządzanych przez zwierzęta na cudzym terenie. Mogły one powstać albo na

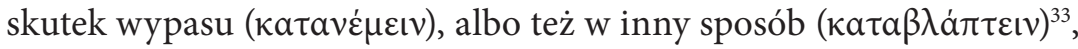
jak możemy przypuszczać przede wszystkim poprzez zadeptanie upraw. Terminologia użyta w tekście, mówiąca o wejściu czy wkroczeniu ( $\dot{\mu} \mu \beta a i v \omega)$ zwierzęcia na cudzy teren, sugeruje, że odnosił się on do sytuacji, w której to same zwierzęta wywołały szkodę, wchodząc na

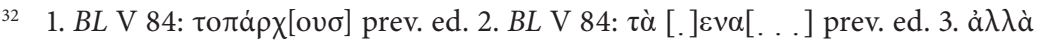

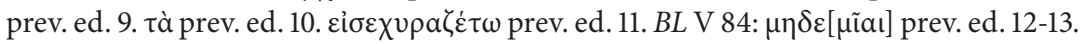

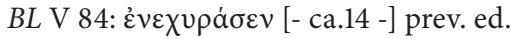

33 J. MéLÈze Modrzejewski, Ulpien et la nature..., s. 192. 
sąsiednie tereny ${ }^{34}$. W zarządzeniu tym wskazano, do czego zobowiązany był w takim przypadku pan zwierząt, przy czym postanowienia te różnie były interpretowane przez badaczy.

Józef Mélèze Modrzejewski chciał widzieć w P. Petr. III 26 świadectwo obowiązywania w Egipcie ptolemejskim rozwiązań przewidujących w przypadku szkód wyrządzonych przez zwierzęta alternatywę pomiędzy wydaniem zwierzęcia a zapłatą odszkodowania, która miałaby być według niego rozwiązaniem typowym dla prawa greckiego. Jako dowód na jej obowiązywanie w prawie greckim, z którego czerpałoby diagramma, jako tekst ustawodawczy wydany przez greckich władców, powołuje się on na fragment Praw Platona (Plat., Leg. XI 936 d-e) $)^{35}$, dotyczący szkód wyrządzanych przez zwierzęta. Wynika z niego, że jeżeli zwierzę pociągowe, koń czy jakiekolwiek inne stworzenie wyrządziło samodzielnie, bez udziału człowieka, szkodę w dobrach sąsiada, właściciel musiał ją zrekompensować, tak jak w przypadku niewolni-

\footnotetext{
34 R. Taubenschlag, Die 'Actio de pastu'..., s. 570.

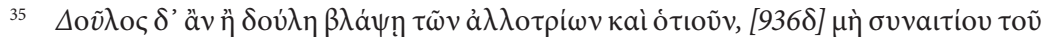

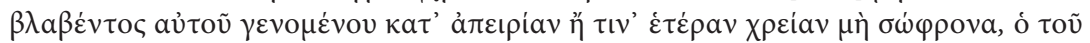

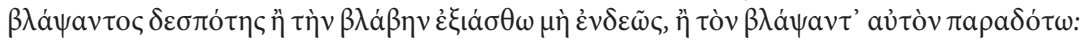

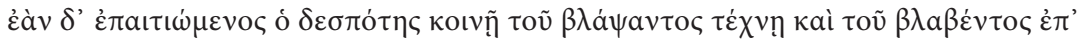

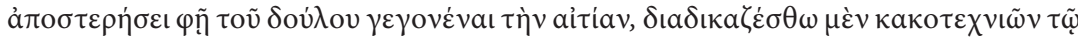

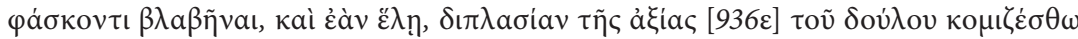

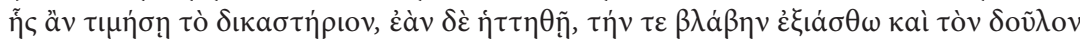

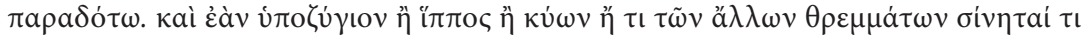

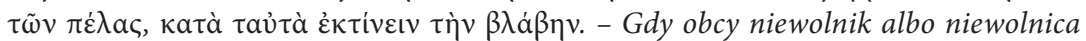
wyrządzi komuś jakąś najmniejszą choćby szkodę w jego dobytku, a poszkodowany nie jest wspótwinny przez swój brak doświadczenia czy nierozsadne jakieś postępowanie, właściciel niewolnika pokryć musi w całej pełni wyrządzona przez niego szkodę lub wydać go poszkodowanemu. W razie zaś, gdyby sam napadał na pokrzywdzonego i upierat się przy tym, że chytrze rzecz cała uknuł wspólnie ze sprawcą szkody, ażeby go pozbawić jego niewolnika, niech oskarżony przed sadem o podstępna zmowę tego, kto się podaje za poszkodowanego; jeżeli wygra, otrzyma od niego sumę wynoszaca dwukrotnq wartość niewolnika, tak jak ją określi sąd, a jeżeli przegra, wyrówna mu szkodę i odda swego niewolnika. Także jeżeli należące do kogoś zwierzę zaprzęgowe albo koń, pies czy inne z jego zwierzat domowych spowoduje szkode u sasiada, właściciel będzie musiał w podobny sposób pokryć straty. Tłumaczenie za: M. May коwska, Platon. Prawa, Warszawa 1960, s. 533-534. 
ków. Oznacza to, że mógł albo zapłacić odszkodowanie, albo też wydać zwierzę, które poszkodowany następnie sprzedawał lub wykorzystywał do pracy na własną rzecz ${ }^{36}$.

Według Modrzejewskiego opisana alternatywa pojawiła się w Grecji archaicznej, początkowo w odniesieniu do stworzenia atakującego człowieka, a następnie została rozciągnięta przez Platona na zwierzęta wywołujące szkody w majątku ${ }^{37}$. Faktycznie fragment Plutarcha, w którym mówi on o ustawodawstwie Solona dotyczącym zwierząt, wskazuje, że przynajmniej w przypadku psa gryzącego człowieka przewidziane było wydanie ( $\pi \alpha \rho a \delta o \tilde{v}$ al) stworzenia poszkodowanemu (Plut., Sol. 24,1) ${ }^{38}$. Jednocześnie występujący na początku tego fragmentu zwrot - $\beta \lambda \alpha \dot{\beta} \eta$ $\tau \varepsilon \tau \rho a \pi o ́ \delta \omega v$, a więc szkoda wyrządzona przez czworonogi, zdaje się stanowić próbę objęcia ogólnym terminem strat powodowanych przez zwierzęta czworonożne. Konkretne uregulowanie dotyczyło jednak psa, który pogryzł człowieka, co było najprawdopodobniej jedną z licznych norm zawartych w ustawodawstwie Solona ${ }^{39}$. Nie do końca wiadomo, czy prawo Solona przewidywało wydanie zwierzęcia w przypadku wszelkich szkód, w tym także tych spowodowanych na skutek wypasu, czy wyłącznie tych wyrządzonych przez stworzenie atakujące człowieka. Za tym drugim rozwiązaniem mógłby przemawiać fakt, że analogiczne

36 J. Mélèze Modrzejewski, Hommes libres..., s. 80-81.

37 Ibidem, s. 81-82.

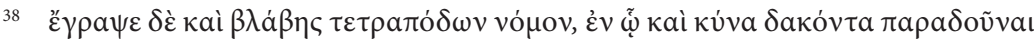

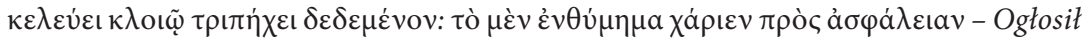
także prawo dotyczące szkód wyrządzonych przez czworonogi, w których nakazuje się wydać psa ze smycza trzyłokciowa przywiazana do niego; to doskonały pomysł służacy bezpieczeństwu. K. Korus, L. Trzcionkowski, Plutarch. Żywoty równoległe, II, Warszawa 2005, s. 88, tłumaczy natomiast drugą część zdania jako: nakazuje się wyposażać psa mogącego ugryźć w łańcuch długości trzech łokci. Tłumaczenie takie, ze względu na

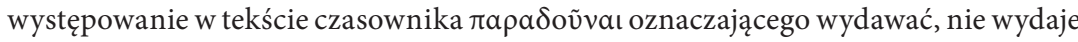
się prawidłowe.

39 E.J. Buis, ¿Antecedentes de la 'actio de pauperie' en el derecho ático? La responsabilidad objetiva y los daños causados por animales domésticos en Atenas y Roma, www. edictum.com.ar/miWeb4/xix/Trabajos/BUIS\%20Emiliano.doc (dostęp: 20 sierpnia 2019 r.); I. Calero Secall, Plutarco y su interpretación de leyes griegas concernientes a la familia y propiedad, [w:] Nomos, Kosmos \& Dike in Plutarch, red. J. Ribeiro Ferreira, D.F. Leão, C.A. Martins de Jesus, Coimbra 2014, s. 60. 
uregulowania do tych przekazanych przez prawo Solona pojawiają się w innych prawach antycznych właśnie w przypadku agresywnych zwierząt, a nie szkód w uprawach ${ }^{40}$. Nie wiemy też, czy w prawie Solona istniała możliwość zapłaty odszkodowania w miejsce wydania zwierzęcia ${ }^{41}$, co wskazywane jest przez Modrzejewskiego jako prawdopodobne ${ }^{42}$. We fragmencie Plutarcha nie mamy jednak do czynienia z jakąkolwiek wzmianką o ewentualnej alternatywie pomiędzy wydaniem zwierzęcia a odszkodowaniem. Być może spowodowane było to tym, że w przypadku psa mieliśmy do czynienia z „dzikim” zwierzęciem, które jako takie nie miało właściciela, który mógłby zapłacić odszkodowanie ${ }^{43}$. W takim przypadku trudno byłoby jednak traktować fragment ten jako poświadczenie obowiązywania odpowiedzialności noksalnej, która ciążyła na właścicielu właśnie.

Potwierdzenie istnienia alternatywy pomiędzy wydaniem zwierzęcia a odszkodowaniem poświadczone jest natomiast w prawie kreteńskim z V w. p.n.e. W tzw. Drugim kodeksie z Gortyny znajduje się wiele postanowień dotyczących szkód wyrządzanych przez zwierzęta innym zwierzętom (IC IV 31, I 1-7, I 12-17-II2). W sytuacji, gdy doprowadziło to do jakiś materialnych uszkodzeń lub też zgonu stworzeń, właściciel poszkodowanego zwierzęcia mógł domagać się od właściciela zwierzęcia będącego sprawcą albo wydania zwierzęcia-sprawcy w miejsce poszkodowanego stworzenia, albo zapłaty odszkodowania w pojedynczej wysokości ${ }^{44}$.

Wskazane klauzule przewidywały zatem następujące trzy rozwiązania:

a. zwierzę powodujące szkodę było przekazywane właścicielowi zwierzęcia, które doznało szkody, przy jednoczesnym przekazaniu poszkodowanego zwierzęcia w drugą stronę;

40 E.J. BuIs, ¿Antecedentes de la 'actio de pauperie'..., s. 5-6.

41 Ibidem.

42 J. MéLÈze ModrzeJewsKi, Ulpien et la nature..., s. 191.

43 I. Calero Secall, Plutarco y su interpretación..., s. 63.

44 Ibidem, s. 61-62; I. CALERo SeCALL, Las leyes creyentes y la responsabilidad noxal por los daños causados por animales y esclavos, «Florentina iliberritana» 25/2014, s. 33-35. 
b. właściciel zwierzęcia powodującego szkodę płacił odszkodowanie, jeżeli właściciel poszkodowanego zwierzęcia odmawiał wymiany zwierząt;

c. właścicielowi poszkodowanego zwierzęcia nie udało się udowodnić szkody, w którym to przypadku nie było podstaw do wniesienia skargi $^{45}$.

Faktycznie znajdujemy zatem w prawie kreteńskim potwierdzenie istnienia alternatywy pomiędzy wydaniem a odszkodowaniem, jednak jej charakter jest istotnie odmienny od tej przedstawionej przez Platona i sugerowanej przez Modrzejewskiego. Omawiane źródło wskazuje na istnienie alternatywy bowiem tylko w przypadku szkód wyrządzanych przez zwierzęta innym zwierzętom, nie ma natomiast w nim jakiejś ogólnej normy, tym bardziej dotyczącej szkód w uprawach. Dodatkowo wydanie zwierzęcia było związane z otrzymaniem w zamian pokrzywdzonego stworzenia.

Można by w związku z tym podnieść, że Prawa Platona są jedynie propozycją, ale Lizjasz poświadcza podwójne odszkodowanie, które należy zapłacić za szkody spowodowane przez niewolnika (Lys. 10, 19) ${ }^{46}$, a i u Platona odpowiedzialność za zwierzęta była taka sama jak za niewolników. Niewykluczone zatem, że w swojej idealnej polis Magnezji Platon, proponując rewizję różnych aspektów obowiązującego ustawodawstwa ateńskiego ${ }^{47}$, zaproponował jego zmianę także w odniesieniu do szkód wyrządzanych przez zwierzęta. W związku z tym uzupełniłby on element wydania zwierzęcia o możliwość zastąpienia go odszkodowaniem. Ewentualnie, jeżeli alternatywa taka znana byłaby już wcześniej, rozciągnąłby ją na przypadki szkód wyrządzonych przez zwierzęta w uprawach.

Fakt przewidywania wydania zwierzęcia lub odszkodowania zarówno przez prawa greckie, jak i rzymskie powoduje, że przyjmuje się, iż system odpowiedzialności noksalnej był właściwy dla antycznych ludów. Była ona powiązana bowiem $\mathrm{z}$ najbardziej prymitywnym sposobem

\footnotetext{
45 I. Calero Secall, Las leyes creyentes..., s. 33-35.

46 I. Calero Secall, Plutarco y su interpretación..., s. 61.

47 E.J. BuIs, ¿Antecedentes de la 'actio de pauperie'..., s. 6.
} 
rozwiązania konfliktów społecznych dotyczących szkód, poprzez wykonanie prawa do zemsty. Zgodnie z tą zasadą właściciel zwierzęcia lub niewolnika powodującego szkodę mógł wydać je w ręce poszkodowanej osoby, dając jej możliwość zemsty ${ }^{48}$. Nie pozwala to jednak automatycznie przyjąć, że obowiązywała ona także w Egipcie ptolemejskim.

Istnienie takiej alternatywy w Egipcie ptolemejskim, jak wskazał sam Modrzejewski, jest bowiem tylko hipotezą, ale według niego wielce prawdopodobną. Powołuje się on w tym zakresie na dokument $P$. Lille I 29=M. Chr. 369=C. Ptol. Sklav. I 1=Jur. Pap. $71^{49}$ (III w. p.n.e., Ghoran), zawierający tekst prawa jednej z greckich polis w Egipcie, Ptolemais lub Naukratis ${ }^{50}$, dotyczącego odpowiedzialności za działania niewolników. Jak z niego wynika, prawo to dopuszczało w pewnych przypadkach wybór pomiędzy wydaniem niewolnika poszkodowanemu a zapłatą odszkodowania $^{51}$. Kol. I 27-II 39 przewidywała, że jeżeli właściciel został uznany odpowiedzialnym za przestępstwo niewolnika (jako inicjator lub świadomy przestępstwa), to wtedy oprócz kary przewidzianej wyrokiem musiał zapłacić dwudziestoprocentowy dodatek. Jeżeli natomiast

48 I. Calero Secall, Las leyes creyentes..., s. 32; I. Calero Secall, Plutarco y su interpretación..., s. 61.

49 O dokumencie tym por. np. E. Berneker, $\mathrm{Zu}$ einigen Prozessurkunden der Ptolemäerzeit, «Études de papyrologie» 2/1933, s. 59-69; L. Gernet, Aspects du droit athénien de l'esclavage, "Archives d'histoire du droit oriental. Revue internationale des droits de l'antiquité» 5/1950-1951, s. 165, 170; S.R. LLEWELYN, Slaves obey your masters': the legal liability of slaves, [w:] New Documents Illustrating Early Christianity VII: A Review of the Greek Inscriptions and Papyri Published in 1982-1983, red. S.R. LLEWELYN, North Ryde 1994, s. 165-196 i bibliografia tam cytowana.

50 Nie ma zgody co do ustawodawstwa, z którego tekst ten pochodzi. Część bada-

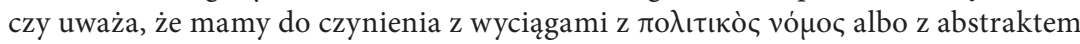
z diagramma królewskiego. Por. dokładniej na ten temat S.R. LlewelYN, op. cit., s. 178-179 i bibliografia cytowana w przyp. 22. O greckim rodowodzie por. S.R. LLEWELYN, op. cit., s. 169; P. Jouguet, P. Collart, J. Lesquier, P. Lille I, s. 129.

${ }^{51}$ ii 25-33: o $\tau 1 \dot{\alpha} \mu \varphi 1 \sigma \beta \eta \tau \eta \varsigma[-c a . ?-\delta 1 \alpha] \gamma \nu \omega \sigma \theta \tilde{\eta} 1, \mu \eta ̀ ~ \varepsilon i ̉ \delta o ́[\tau o \varsigma \alpha v ่ \tau o \tilde{v} \mu \eta \delta \grave{\varepsilon}] \kappa \varepsilon \lambda \varepsilon v ́ o v \tau o \varsigma$,

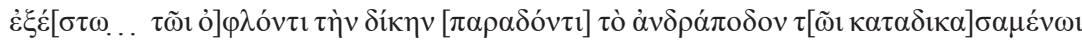

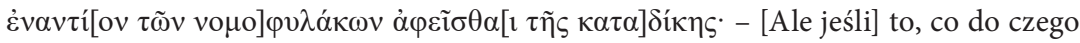
spierał się w [postępowaniu], zostało zadecydowane, jeśli nie wiedział, lub nie rozkazał [niech będzie zobowiązany] przegrany (właściciel) [wydać] niewolnika przed nomofylaksem [powodowi] i zwolnić go z osądu. 
nie został uznany za współwinnego (a więc niewolnik działał z własnej inicjatywy), a odpowiadał tylko jako właściciel, to mógł się uwolnić od płacenia odszkodowania przez noxae datio - wydanie niewolnika poszkodowanemu ${ }^{52}$.

Modrzejewski, powołując się na $P$. Lille I 29, wskazywał na właściwe według niego dla praw greckich obowiązywanie takich samych zasad odpowiedzialności za niewolników i zwierzęta. Świadectwem przemawiającym bezpośrednio za taką analogią jest omówiony już tekst Platona, którego obowiązywania nie możemy być pewni ${ }^{53}$. W odniesieniu do prawa attyckiego Harrison wątpi jednak, że dokonywano wydania noksalnego niewolnika, ponieważ nie ma praktycznie w tym zakresie świadectw ${ }^{54}$. Wprawdzie Prawo Gortyny (IC IV 47.1-8) zawiera postanowienia dotyczące deliktów popełnionych przez niewolników, przewidując w takiej sytuacji odpowiedzialność noksalną ciążącą na właścicielu niewolnika ${ }^{55}$, ale miała ona odmienny charakter niż ta przewidziana u Platona. W prawie kreteńskim skarga noksalna była skierowana przeciwko osobie, której przysługiwało prawo własności nad niewolnikiem, o ile sprawca działał na własny rachunek i ryzyko, gdyż w razie działania z polecenia skargę kierowano przeciwko tej osobie (IC IV 47) ${ }^{56}$. Co jednak bardzo ważne, właściciel niewolnika musiał zapłacić karę pieniężną właścicielowi uszkodzonych dóbr, jak i wydać mu niewolnika. Nie mieliśmy tutaj zatem do czynienia z rozłączeniem, ale kumulacją, jako że obowiązkowe wydaje się, oprócz odszkodowania, także dostarczenie ofierze sprawcy w przeciwieństwie do odpowiedzialności za zwierzęta. Nie widzimy tutaj zatem typowej alternatywy noksalnej, chyba żeby przyjąć, iż koniunkcja miała w tym przypadku rozłączną wartośćc ${ }^{57}$, ale źródła przeczą takiej możliwości.

52 I. BieżuńsKa-MaŁowist, Sytuacja społeczna niewolników w Egipcie Ptolemejskim, Warszawa 1976, s. 17-18.

53 J. MéLÈze Modrzejewski, Ulpien et la nature..., s. 191-192 i przyp. 72.

54 A.R.W. Harrison, The Law of Athens. The Family and Property, Oxford 1968, s. 174.

55 I. Calero Secall, Plutarco y su interpretación..., s. 62.

56 I. Calero Secall, Las leyes creyentes..., s. 37-38.

57 Ibidem, s. 40. 
W peloponeskim mieście Andania w I w. p.n.e. przewidywano natomiast, że w razie przyłapania niewolnika na popełnianiu deliktu, konieczne było zapłacenie za skradzioną rzecz oraz kary w wysokości 20 drachm. Jeśli nie dokonano natychmiastowej zapłaty, właściciel niewolnika musiał wydać niewolnika poszkodowanemu, aby mógł on uregulować dług swoją pracą (IG V, 1, 1390, 77-78). W tym przypadku wydaje się jednak, że przekazanie niewolnika było czasowe i nie oznaczało przeniesienia prawa własności ${ }^{58}$.

Jak zatem widzimy, tylko u Platona znajdujemy identyczne ukształtowanie odpowiedzialności za szkody wyrządzane z własnej inicjatywy przez niewolników i zwierzęta. Modrzejewski uważa jednak wyraźne poświadczenie alternatywy pomiędzy odszkodowaniem a wydaniem noksalnym w P. Lille I 29 w odniesieniu do niewolników za przekonujący argument za przyjęciem hipotezy, że w Egipcie ptolemejskim również w przypadku odpowiedzialności za zwierzęta, o której mowa jest w P. Petr. III 26, przyznany był właścicielowi wybór pomiędzy wydaniem „winnego” zwierzęcia a naprawieniem szkody ${ }^{59}$.

Hipoteza ta jest wprawdzie kusząca, szczególnie że alternatywa taka dopuszczana była przez Platona tylko w ściśle określonym przypadku braku czynnego udziału właściciela zwierzęcia w wyrządzeniu szkody, a ich samodzielnego spowodowania przez stworzenie (wyłączną odpowiedzialność odszkodowawczą przewidywał też sam Platon w przypadku nielegalnego wypasu, a więc przy czynnym udziale człowieka ${ }^{60}$ ), któremu można było przypisać „winę”, której to sytuacji dotyczył także

58 Ibidem.

59 J. Mélèze Modrzejewski, Hommes libres..., s. 82-83.

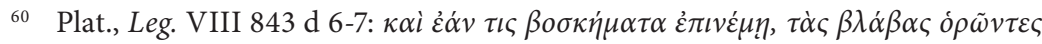

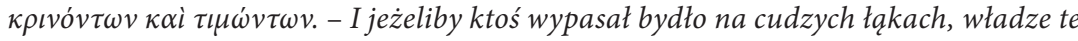
będa również rozpatrywać, stwierdzać i oceniać szkodę. Tłumaczenie za M. MАYкоw-

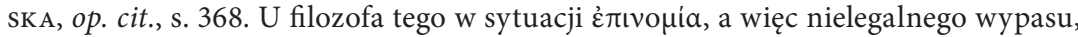
w przeciwieństwie do innych przypadków odpowiedzialności za materialne szkody wyrządzone przez zwierzęta, nie była wskazana możliwość dokonania wydania

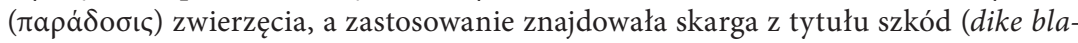
bes), kierowana bezpośrednio przeciwko właścicielowi zwierzęcia (lub pasterzowi). Przy wypasie brakowało bowiem przesłanek do uznania istnienia odpowiedzialności noksalnej, bowiem to wola właściciela doprowadziła zwierzę do działania i samemu 
P. Petr. III 26. Zgadza się to z postanowieniami P. Lille 29, zgodnie z którymi, tylko gdy niewolnik działał samodzielnie, bez rozkazu i wiedzy swego pana, właściciel mógł zwolnić się z odpowiedzialności poprzez wydanie niewolnika powodowi przed nomofylaksem. Jeżeli natomiast właściciel wiedział o działaniu niewolnika albo je nakazał, to nie miał możliwości przekazania go poszkodowanemu i pozostawało mu zapłacenie odszkodowania ${ }^{61}$.

Papirus P. Petr. III 26 dotyczył zatem sytuacji analogicznej do tej opisanej we fragmencie XI 936 d-e Praw Platona, ale w tekście diagramma nie ma żadnego, nawet najmniejszego wskazania na możliwość wydania zwierzęcia, którego, w związku z tym, że mamy do czynienia z zarządzeniem królewskim, a więc tekstem ustawodawczym, a nie dokumentem praktyki, spodziewalibyśmy się w nim, tak samo jak w $P$. Lille I 29. Dziwne i mało możliwe wydaje się bowiem, aby ustawodawca pominął w prawie stanowionym tak istotny element, jak alternatywny sposób zwolnienia się z odpowiedzialności, jeżeli faktycznie miał on obowiązywać. Jeżeli miano by go na myśli, to by o nim wspomniano, na przykład poprzez zamieszczenie terminu $\pi \alpha \rho a \delta i \delta \omega \mu$ - wydawać, poświadczonego zarówno u Plutarcha, Platona, jak i uzupełnianego w P. Lille I 29.

Bardzo ważne również, aby nie zestawiać tak wprost ze sobą dwóch powoływanych wyżej dokumentów papirusowych. P. Lille I 29 zawiera regulacje o greckim rodowodzie, jako że stanowiły one prawo którejś z greckich poleis. Takiej pewności nie możemy natomiast mieć w przypadku P. Petr. III 26. Jest to wprawdzie tekst ustawodawczy, wydany przez macedońskich władców, co mogłoby sugerować także stosowanie tutaj prawa greckiego i co Modrzejewski, jak i Taubenschal (mówił on o stosowaniu w tym przypadku skargi dike blabes ${ }^{62}$ przyjęli za pewnik, ale nie możemy być tego całkowicie pewni. Jest to raczej przejawem grekocentryzmu. Prawo to obowiązywało bowiem na terenie całego Egiptu i jako takie mogło podlegać lokalnym oddziaływaniom. Pod ich

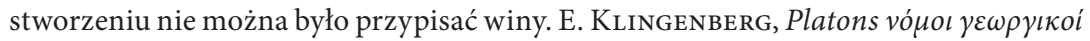
und das positive griechische Recht, Berlin 1976, s. 36-37.

61 S.R. LlewElyn, op. cit., s. 178-179.

62 R. Taubenschlag, Die 'Actio de pastu'..., s. 568. 
wpływem prawo greckie mogło ulec zmianom albo też mogło dojść do przejęcia prawa lokalnego. Nie możemy również wykluczyć ewentualnej samoistnej ewolucji prawa greckiego, prowadzącej do odejścia od zemsty na zwierzęciu w przypadku szkód wyrządzonych przez nie.

Biorąc wszystko to pod uwagę, hipoteza Modrzejewskiego o obowiązywaniu w Egipcie ptolemejskim alternatywy pomiędzy wydaniem zwierzęcia a zapłatą odszkodowania w oparciu o P. Petr. III 26 wydaje się mało możliwa. Zdecydowanie bardziej prawdopodobna jest natomiast interpretacja tego dokumentu przedstawiona przez Marie-Thérèse Lenger. Zgodnie z nią, to, co charakteryzowało prawo ptolemejskie w zakresie odpowiedzialności za szkody wyrządzone przez zwierzęta, to wysoki stopień rozwoju, przejawiający się w sposobie naprawienia wyrządzonej szkody, w którym brakuje jakiejkolwiek pozostałości zemsty dokonywanej na zwierzęciu - sprawcy szkód, z którą mielibyśmy do czynienia w razie konieczności wydania zwierzęcia będącego sprawcą strat osobie poszkodowanej, czy o alternatywie pomiędzy wydaniem zwierzęcia a odszkodowaniem pieniężnym ${ }^{63}$. Zarządzenie królewskie przewidywało bowiem jedynie obowiązek pana zwierzęcia (кúpıos, którym mógł być równie dobrze właściciel, jak i pasterz ${ }^{64}$ ) do zapłacenia odszkodowania, odpowiadającego wysokości poniesionych szkód, które miały być określone w wyroku odpowiednich władz.

Dodatkowo prawo zawarte w P. Petr. III 26 zakazywało wszelkich form samopomocy czy jednostronnej egzekucji, zastrzegając wyłącznie na rzecz sądu oszacowanie wysokości poniesionych szkód i zasądzenie odszkodowania ${ }^{65}$. Zakaz taki został wyrażony w tekście za pomocą

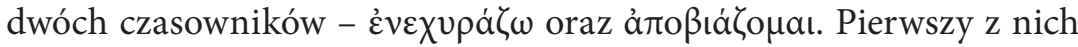
przetłumaczony został przez Lenger po prostu jako „saisir”, a więc „chwycić, złapać"66, a przez innych badaczy zajmujących się tym tekstem interpretowany był zazwyczaj jako zakaz wzięcia zwierzęcia w zastaw

M.-Th. Lenger, op. cit., s. 465.

J. MéLÈze Modrzejewski, Ulpien et la nature..., s. 193.

M.-Th. LENGER, op. cit., s. 465.

Ibidem, s. 461. 
dla zabezpieczenia pokrycia szkód ${ }^{67}$. W prawie greckim czasownik $\varepsilon \dot{\varepsilon} v \chi \cup \rho a ́ \zeta \omega$ był stosowany jednak wyłącznie na określenie zajęcia przedmiotu w postępowaniu egzekucyjnym mającym miejsce po niewykonaniu zobowiązania, $\mathrm{z}$ albo bez wyroku sądowego, tam, gdzie nie ustanowiono zabezpieczenia ${ }^{68}$. Oznaczał on zatem także w kontekście diagramma, raczej zakaz przeprowadzenia postępowania egzekucyjnego bez wcześniejszego wyroku.

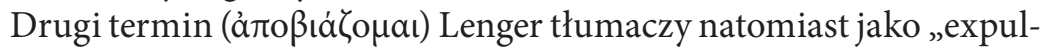
sion", a więc wydalenie, wypędzenie (zwierzęcia) ${ }^{69}$, co nie wydaje się właściwe. Mało prawdopodobne wydaje się, aby właściciel czy dzierżawca pola, na którym wypasały się cudze zwierzęta, nie mógł ich przepędzić $\mathrm{z}$ własnego terenu dla uniknięcia dalszych strat ${ }^{70}$. To mógł zrobić, co poświadczone jest w wyliczonych już wcześniej petycjach. Omawiany termin oznaczał zatem raczej zakaz zastosowania jakiejkolwiek formy przemocy ${ }^{71}$, czy jak tłumaczy to Modrzejewski - sprawiedliwości prywatnej ${ }^{72}$.

Jeżeli właściciel zniszczonego terenu dopuścił się któregoś z tych naruszeń, sam podlegał sankcji, polegającej na obowiązku zapłaty kary w wysokości $1000 \mathrm{drachm}$ i zwróceniu tego, co zabrał panu zwierzęcia ${ }^{73}$. Realizacja tych obowiązków miała być zagwarantowana przez królewskiego poborcę podatkowego ${ }^{74}$, co sugeruje, że wskazana grzywna przypadała na rzecz skarbu państwa ${ }^{75}$.

67 M. Jager, M. Reinsma, Ein missverstandenes Gesetz aus ptolemäischer Zeit, [w:] Pap. Lugd. Bat. XIV, Leiden 1965, s. 115, tłumaczy go jako pfänden; R. TAubeNschlag, Selfhelp in Greco-Roman Egypt, [w:] R. Taubenschlag, Opera Minora, II, Warszawa 1959, s. 136.

68 M.I. Finley, Studies in Land and Credit in Ancient Athens, 500-200 B.C., The Horos Inscriptions ${ }^{2}$, Oxford 1985, s. 29.

69 M.-Th. Lenger, op. cit., s. 465.

70 M. Jager, M. Reinsma, op. cit., s. 114-115.

71 Ibidem, s. 115.

72 J. MÉLÈze Modrzejewski, Ulpien et la nature..., s. 193 - „justice privée”.

73 M.-Th. Lenger, op. cit., s. 467.

74 O kompetencjach tych urzędników por. S. PŁodzień, The origin and competence

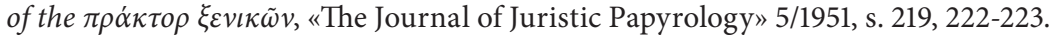

75 M.-TH. LENGER, op. cit., s. 467. 
Przewidzenie takich sankcji wskazuje, że poza faktem samego wyrządzania szkód i ich naprawienia władca ptolemejski skupiał swoją uwagę również na pomocy własnej stosowanej najprawdopodobniej często w przypadku szkód wyrządzanych przez zwierzęta w uprawach. Polegalaby ona na zajęciu zwierzęcia powodującego straty, w celu powetowania sobie poniesionych strat albo zmuszenia właściciela do ich pokrycia. Władca zakazywał wyraźnie tego rodzaju praktyk, nakazując czekać na rozstrzygnięcie sprawy przez sąd. Zakaz zajmowania zwierzęcia przed procesem oznaczał zatem niedopuszczalność stosowania samopomocy, z czego ponownie nie wynika, żeby diagramma przewidywało jako sposób pokrycia szkód oddanie zwierzęcia w miejsce odszkodowania.

P. Petr. III 26 wyraźnie wskazuje bowiem, że w przypadku szkód wyrządzonych przez same zwierzęta na sąsiednich terenach, domagano się wyłącznie naprawienia szkód poprzez zapłatę ich równowartości (Taubenschlag mówił o stosowaniu w tym przypadku greckiej skargi dike blabes przewidującej obowiązek zapłaty odszkodowania $)^{76}$. Brak w nim natomiast jakichkolwiek śladów alternatywy pomiędzy zapłatą odszkodowania a wydaniem zwierzęcia, co miałoby być rozwiązaniem przewidzianym w diagramma według hipotezy Modrzejewskiego.

76 R. Taubenschlag, Die 'Actio de pastu'..., s. 568. Była to prywatna skarga o szkody, znana dobrze prawu ateńskiemu. W jego ujęciu pojęcie $\beta \lambda \alpha \dot{\beta} \eta$, a więc szkody, było szerokie i obejmowało wszelkiego rodzaju fizyczne i materialne straty poniesione przez powoda na skutek działania lub zaniechania pozwanego (S.C. ToDD, The Shape of Athenian Law, Oxford 1993, s. 366; J. VÉlissaropoulos-Kara kostas, Remarques sur la responsabilité civile en Grèce, "Cahiers du Centre Gustave Glotz» 9/1998, s. 74-75). Prawo to przewidywało konieczność zapłaty podwójnej wartości szkód, jeżeli zostały one wyrządzone celowo, lub pojedynczej, jeżeli nastąpiło to przypadkowo (Dem., Or. XXI 25 i 43). D.M. MacDowell, The Law in Classical Athens, London 1986, s. 149-151. W prawie ateńskim skarga ta znajdowała zastosowanie w bardzo zróżnicowanych przypadkach, co doprowadziło Wolffa do sformułowania stwierdzenia, że nie była to pojedyncza skarga, ale grupa postępowań, z których każde dotyczyło wydzielonej

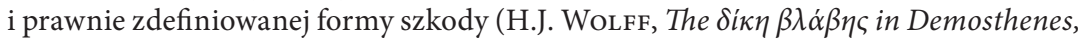
Or. $L V$, «The American Journal of Philology» 64.3/1943, s. 323). Według innych jednak był to generalny termin obejmujący różne działania lub zaniechania powodujące przede wszystkim szkody materialne (S.C. TodD, op. cit., s. 279). 
Nawet próba wyjaśnienia takiego braku w ten sposób, że wydanie zwierzęcia nie było operacją typu noksalnego, jakim mogło być ono w Grecji archaicznej i klasycznej, ale sposobem pokrycia należnego odszkodowania w miejsce zapłaty, nie wydaje się przekonujące. W sytuacji uiszczenia odszkodowania w ten właśnie sposób zawsze konieczne byłoby bowiem wydanie zwierzęcia poszkodowanemu, o której to możliwości diagramma powinno wspominać. Ewentualnie stworzenie mogło być sprzedane przez jego właściciela czy pasterza, który uzyskiwał w ten sposób środki potrzebne do pokrycia szkód. W takim przypadku rzeczywiście nie byłoby potrzebne wspominanie w zarządzeniu królewskim o wydaniu zwierzęcia, ale to dlatego, że do niego nie dochodziło. Poszkodowany dostawał jedynie pieniądze, a sprzedaż zwierzęcia była decyzją właściciela, który mógł wybrać taki właśnie sposób zaspokojenia roszczeń, szczególnie jeżeli zwierzę należało do cenniejszych rzeczy należących do niego. Nie znajdujemy zatem w P. Petr. III 26 żadnych wskazówek co do istnienia innego sposobu pokrycia szkód, jak poprzez zapłatę odszkodowania.

Bardzo pomocne w celu definitywnego odrzucenia hipotezy Modrzejewskiego byłoby posiadanie dokumentów praktyki, wskazujących na taki, a nie inny charakter odpowiedzialności. Dysponujemy wprawdzie petycjami zachowanymi na papirusach, dotyczącymi szkód wyrządzanych przez zwierzęta, ale niestety nie są one jednoznaczne.

Dwie datowane, tak jak diagramma, na III w. p.n.e., petycje - P. Enteux. $65^{77}$ oraz być może P. Enteux. 75 (tekst ten w najbardziej interesującym nas miejscu ma lakunę) ${ }^{78}$ dotyczyły bowiem przypadku celowego

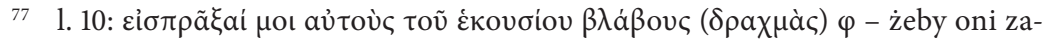
płacili mi 500 (drachm) za świadomie (wyrządzone) szkody. Jako przykład dike blabes petycja ta interpretowana jest przez Bitonto. A. Di Bitonto, Le petizioni al re: studio sul formulario, «Aegyptus» 47/1967, s. 31.

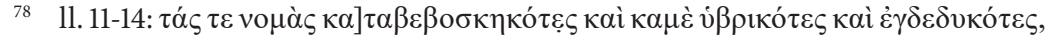

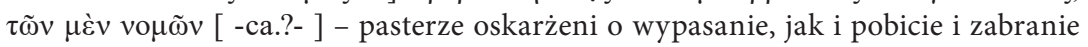
ubrania, pasterzy [----------]; jeśli chodzi o delikt pobicia, Diofanes niech zadecyduje. Taubenschlag proponował uzupełnienie lakuny w tym tekście zwrotem

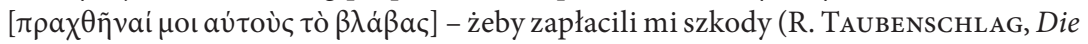
Actio de pastu..., s. 568), ale ze względu na stan zachowania dokumentu jest to jedynie hipoteza. Wziąwszy jednak pod uwagę fakt, że wnoszący petycję osobno domagał się 
puszczenia stworzeń na obce tereny ${ }^{79}$. Jak wskazują te dokumenty, wówczas żądanie poszkodowanych było ograniczone jedynie do wypłaty odszkodowania.

Wydaje się zatem, że przynajmniej w III w. p.n.e. żądania stron, których pola zostały zniszczone przez zwierzęta, niezależnie od tego, czy nastąpiło to przy udziale człowieka, czy też nie, ograniczały się do wniosku o pokrycie szkód. Takie rozwiązanie, w świetle zachowanych do naszych czasów źródeł, miałoby zastosowanie przynajmniej do ziemi należącej do kategorii kleros, a więc działek przyznawanych żołnierzom greckiego i macedońskiego pochodzenia (kleruchowie) w zamian za służbę wojskową ${ }^{80}$ oraz winnic czy ogrodów. Te trzy kategorie wymienione są zarówno w P. Petr. III 26, jak i dotyczą ich petycje z III w. p.n.e.

Nie zawsze jednak w dokumentach związanych ze szkodami wyrządzanymi przez zwierzęta w uprawach z okresu ptolemejskiego jest mowa o zapłacie odszkodowania. Pewne odrębności w tym zakresie zdają się wynikać z dokumentów z II w. p.n.e.

Prośba zawarta w P. Hels. I 31, datowanym na 160 p.n.e. i pochodzącym z nomu herakleopolitańskiego jako pierwsza wskazuje na odmienny charakter odpowiedzialności (1l. 26-32):

$\dot{\alpha} \xi 1 \tilde{\omega} \pi \rho 0 \sigma \kappa\left[\lambda_{-}\right]$

$\eta \theta \tilde{\eta} v \alpha \imath^{81}, \dot{\omega} \varsigma \tilde{\omega} \nu \kappa \tau \eta \nu \tilde{\omega} \nu \kappa \alpha \grave{\imath}$

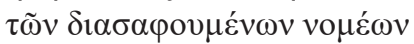

rozstrzygnięcia kwestii pobicia, pierwsza część żądania musiała odnosić się do zniszczenia upraw. Uzupełnienie Taubenschlaga wydaje się w związku z tym prawdopodobne, szczególnie że odpowiada dobrze liczbie brakujących liter, jak i dlatego, że znajdujemy paralele $w$ innych dokumentach ptolemejskich związanych ze szkodami, np. BGU VI 1252 (II w. p.n.e., nom arsinoicki); P. Tor. Amen 8 (116 p.n.e., Teby). Patrząc na analogie,

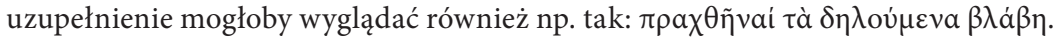

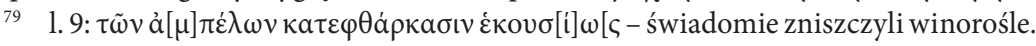

80 S. Reden von, Money in Ptolemaic Egypt: from the Macedonian Conquest to the End of the Third Century BC, Cambridge 2010, s. 88-89; A.B. LLOYd, The Ptolemaic period, [w:] The Oxford History of Ancient Egypt, red. I. SHAw, Oxford 2002, s. 404-405.

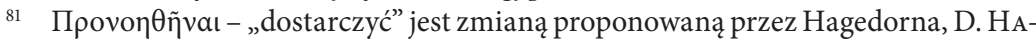
GEDorn, Bemerkungen zu Urkunden, «Zeitschrift für Papyrologie und Epigraphik» 136/2001, s. 151. Chodziłoby tutaj o doprowadzenie sprawców przed urzędnika, a więc znaczenie pozostawało zasadniczo bez zmian. 
$\grave{\alpha} v \alpha \chi \theta \varepsilon \dot{\varepsilon} v \omega \nu \tau \alpha \tilde{v} \tau \alpha \mu \grave{\varepsilon} v \pi \rho \alpha \theta \tilde{\eta} 1$

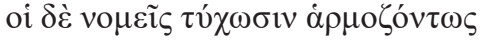

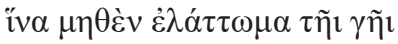

$\grave{\alpha} v \alpha \varphi \varepsilon ́ \rho \eta \tau \alpha$.

Proszę, żeby zostali wezwani i żeby stada i wymienieni pasterze zostali przyprowadzeni, one zostały sprzedane, zaś pasterze doznali tego co się należy, aby żadna strata nie została spowodowana ziemi.

Jest to petycja do oikonomosa Stratona od Diodora będącego rolnikiem królewskim uprawiającym kleros Melanthiosa. Skarżył się on na szkody wyrządzone przez cudze owce oraz na pobicie, którego dopuścili się wobec niego pasterze. Ze względu na stan zachowania dokumentu nie do końca wiadomo, w jakich okolicznościach doszło do zniszczenia upraw. Z jednej strony zastosowana $\mathrm{w}$ nim formuła $\mathrm{z}$ czasownikiem

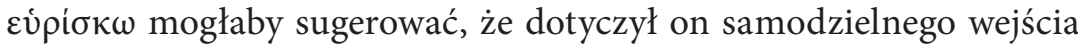
zwierząt na sąsiedni teren. Z drugiej jednak strony, skoro został on pobity przez pasterzy, to musieli być oni świadomi faktu wypasania się zwierząt na cudzym polu, a więc sami mogli je tam wprowadzić.

Jak wynika z papirusu, zwierzęta, które wyrządziły szkody, po przyprowadzeniu ich przed oikonomosa wraz z ich pasterzami, miały zostać sprzedane. Jak można zakładać, miało to na celu uzyskanie pieniędzy na pokrycie strat przez nie spowodowanych. Pojawia się pytanie, przez kogo zbycie to miało być dokonane - czy przez pasterza, samego poszkodowanego czy też przez jakiegoś urzędnika państwowego. Odpowiedź na to pytanie wyłącznie w oparciu o omawiany dokument jest zasadniczo niemożliwa ze względu na jego zwięzłość. Zbycie przez samego poszkodowanego wydaje się mało prawdopodobne, gdyż wówczas Diodor występowałby raczej z prośbą o wydanie mu zwierząt. Pozostają zatem dwie możliwości - albo poszkodowany wskazywał źródło pozyskania środków do zapłaty odszkodowania przez pasterza, albo też sprzedażą zwierząt mieli zająć się urzędnicy. W pierwszej sytuacji nadal żądanie strony koncentrowałoby się na zapłacie odszkodowania, przy podkreśleniu sposobu pozyskania środków; druga implikowałaby konieczność wcześniejszej konfiskaty zwierząt. 
Występująca w $P$. Hels. I 31 wzmianka o wymierzeniu pasterzom tego, na co zasługiwali, wyrażona $\mathrm{w}$ formule $\tau \dot{\chi} \chi \omega \sigma \iota v \dot{\alpha} \rho \mu \mathrm{o}\left\langle\dot{o} v \tau \omega \varsigma^{82}\right.$, powszechnie interpretowanej jako wniosek o ukaranie sprawcy, najczęściej poprzez obowiązek zapłaty kary ${ }^{83}$, mogłaby przemawiać za drugim rozwiązaniem i oznaczać w kontekście omawianego papirusu zastosowanie sankcji w postaci konfiskaty zwierzęcia. Nie możemy być jednak tego pewni, bowiem nie do końca wiadomo, czy żądanie ukarania dotyczyło szkód wyrządzonych przez zwierzęta, czy też pobicia, które towarzyszyło próbie usunięcia stworzeń z pola.

Podobne sformułowanie do tego występującego w P. Hels. I 31, o wymierzeniu tego, co się należy pasterzowi, znajduje się także w o dwa lata młodszym od niego dokumencie - P. Heid. IX $422^{84}$ (158 p.n.e.). Jest to petycja do basilikos grammateusa Dionysiosa od rolnika królewskiego Pachatosa, skarżącego się, że zwierzęta archifylakitesa Seleukosa wypasały się na jego działce, zjadając szesnaście artab roślin pastewnych. W jej przypadku również nie jest jednak pewne, czy ukaranie dotyczyło kwestii wyrządzenia szkód na skutek wypasu zwierząt czy też pobicia, którego dopuścili się pasterze chcący odzyskać swoje zwierzęta.

W związku z powiązaniem obydwu omówionych powyżej papirusów z bójkami, nie możemy być pewni, czy wniosek o ukaranie odnosił się w nich do szkód spowodowanych przez zwierzęta, czy też naruszeń cielesnych. Faktem pozostaje jednak żądanie sprzedania zwierząt zawarte w P. Hels. I 31.

Na całkowicie odmienną od zapłaty odszkodowania odpowiedzialność w przypadku szkód wyrządzanych przez zwierzęta wskazuje bez wątpienia natomiast papirus ze 113 r. p.n.e., dotyczący ziemi królewskiej - P. Tebt. I 27 (1l. 71-75):

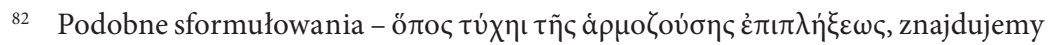
np. w PSI V 542; P. Tebt. I 183; BGU VI 1252; BGU VI 1253.

83 A. Di Bitonto, Frammenti di petizioni del periodo tolemaico. Studio sul formulario, «Aegyptus» 56/1976, s. 131.

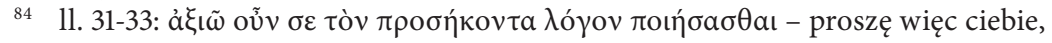
żeby zostały podjęte stosowne środki. 


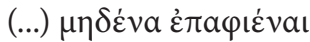

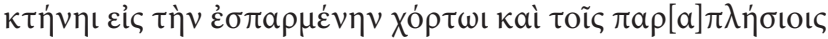
$\gamma \varepsilon v \eta \dot{[}[\mu \alpha \sigma \mathrm{l}]$

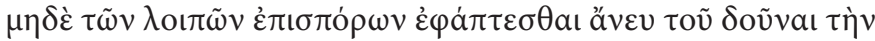

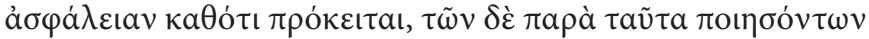
$\tau$ tá $\tau \varepsilon$

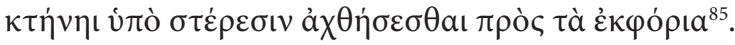

(...) nikt nie powinien puszczać stad na grunt zasiany roślinami pastewnymi i podobnymi produktami, ani zagarniać pozostałych zbiorów bez dania zabezpieczenia ${ }^{86}$, jak jest powyżej, zaś stado tych, którzy uczynią coś z tych rzeczy będzie skonfiskowane dla pokrycia czynszu.

Linie te stanowią fragment dokumentu zawierającego list skierowany przez diojkete Eirenaiosa do Hermaisa, zarządcy ziemi królewskiej, dotyczący konieczności przygotowania listy mieszkańców poszczególnych komogrammatei, z których następnie mieli być wybrani $\gamma \varepsilon v \eta \mu \alpha \tau o \varphi v ́ \lambda \alpha \kappa \varepsilon \varsigma$, mający za zadanie chronić plony i pola należące do kategorii ziemi królewskiej. Ci ostatni funkcjonariusze wraz z innymi strażnikami mieli złożyć przysięgi o prawidłowym wykonywaniu swoich obowiązków. Kopia tego listu została wysłana do Asklepiadesa i basilikos grammateusa, którzy ze swojej strony przesłali go dalej do topogrammateusów i komogrammateusów nomu, polecając im sporządzenie wskazanej listy. Kopie przysiąg złożonych przez nowo mianowanych funkcjonariuszy miały być złożone w banku królewskim, a następnie opublikowane, tak aby nikt nie puszczał zwierząt na tereny królewskie. Sankcją za takie naruszenie była konfiskata zwierząt na rzecz skarbu

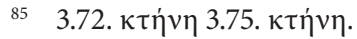

86 To drugie postanowienie odnosi się w sposób bezpośredni do wcześniejszych linii tekstu przewidujących, że nowo mianowani urzędnicy mieli strzec, aby nikt z rolników uprawiających ziemię królewską i tę należącą do kategorii ziemi દ̉v ả $\varphi \dot{\varepsilon} \sigma \varepsilon$ nie zagarniał paszy $\mathrm{i}$ innych podobnych plonów, $\mathrm{z}$ wyjątkiem tych przeznaczonych na paszę dla zwierząt wykorzystywanych w rolnictwie, które miały być zaopatrzone za zgodą komogrammateusa, i z wyjątkiem tych, za które cena i zabezpieczenie miały być zapłacone i złożone w banku w celu pokrycia zobowiązań wobec skarbu królewskiego (11. 54-59). 
państwa, co miało służyć pokryciu utraconego czynszu. Jak wskazuje

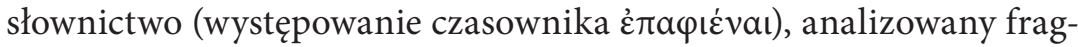
ment dotyczył najprawdopodobniej świadomego, celowego wpuszczania zwierząt na tereny uprawne, a więc problemu nielegalnego wypasu, i w sposób wyraźny odnosił się wyłącznie do ziemi królewskiej.

Sankcja w postaci konfiskaty zwierzęcia, która pojawia się w tym dokumencie po raz pierwszy wyraźnie w źródłach z Egiptu, stanowiła zarówno karę dla właściciela czy pasterza zwierzęcia, jak i sposób wzbogacenia się skarbca królewskiego.

Według Modrzejewskiego tekst ten stanowi świadectwo ogólniejszej i głębszej zmiany w karaniu szkód wyrządzanych przez zwierzęta ${ }^{87}$. Wydanie noksalne, które miałoby być, zgodnie z jego hipotezą, przewidziane w P. Petr. III 26 i stanowić fakultatywny sposób naprawienia szkody, zostałoby zastąpione konfiskatą zwierzęcia, przy czym poszkodowany, niemający nic z przepadku zwierzęcia na rzecz skarbu państwa (poza ewentualnym zwolnieniem z konieczności zapłaty podatków), mógłby dodatkowo domagać się od sprawcy naprawienia szkód.

Interpretacja Modrzejewskiego o występowaniu w tym dokumencie odpowiedzialności zarówno względem państwa, jak i poszkodowanego wydaje się prawdopodobna. Fakt przeznaczenia skonfiskowanego zwierzęcia na pokrycie czynszu sugeruje, że stworzenie przechodziło na własność skarbu państwa, ale jednocześnie z zapłaty obciążeń publicznych zwolniony był poszkodowany rolnik królewski, który w przeciwnym razie byłby zobowiązany do ich uiszczenia. Szkody przez niego poniesione mogły być jednak wyższe niż wartość samego czynszu i prawdopodobne wydaje się, że w tym zakresie mógł się on domagać dodatkowego odszkodowania ${ }^{88}$. W przeciwnym bowiem razie, gdyby pole zostało całkowicie zniszczone, nie miałby on środków do życia. Nie można jednocześnie wykluczyć, że przynajmniej częściowo szkody te były pokrywane z nadwyżki pochodzącej ze sprzedaży zwierzęcia, jeżeli taka pozostała po zaspokojeniu roszczeń państwa.

87 J. MÉLÈze Modrzejewski, Ulpien et la nature..., s. 193.

88 J. MéLÈze Modrzejewski, Papyrologie et histoire des droits de l'Antiquité, [w:] École pratique des hautes études, 4e section, Sciences historiques et philologiques. Annuaire 1973-1974, Paris 1974, s. 234. 
Należy wyraźnie podkreślić, że $P$. Tebt. I 27 przewidywał taki charakter odpowiedzialności bezpośrednio jedynie $\mathrm{w}$ stosunku do ziemi królewskiej i to zasianej roślinami pastewnymi. Pojawia się w związku z tym pytanie, jakich kategorii ziemi dotyczyła tego rodzaju sankcja i czy konfiskata zwierząt została wprowadzona dopiero w 113 r. p.n.e., czy też znana była już wcześniej, oraz czy jej aplikacja była później kontynuowana.

Nie można wykluczyć, że dwie omówione wcześniej petycje, które również dotyczyły ziemi królewskiej i w których pojawia się wzmianka o karaniu pasterzy i sprzedaży zwierząt, przewidywały już wcześniej taką sankcję, ale ich niejednoznaczność nie pozwala na pewne tego stwierdzenie. Nie do końca wiadomo natomiast, czy znajdowała ona aplikację także w I w. p.n.e. Podwójne żądanie, łączące w sobie wniosek o odszkodowanie i ukaranie sprawców, występowało wprawdzie być może w najmłodszej petycji z okresu ptolemejskiego dotyczącej szkód wyrządzonych w uprawach przez zwierzęta - P. Ryl. II 69 (34 p.n.e.) $)^{89}$, ale interpretacja tego dokumentu nie jest łatwa. Była to skarga skierowana do nieznanego urzędnika przez Harnesisa i Onnofrisa, rolników w służbie eklogistesa Achillesa, którzy skarżyli się, że Harmiusis spasł swoimi owcami 15 artab krokoszu, w związku z czym domagali się oni zwrotu zniszczonych plonów oraz wymierzenia sprawcy kary (1l. 13-18):

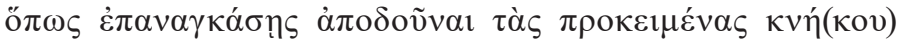

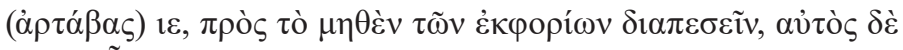

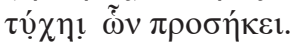

abyś zmusił (go), żeby zwrócił wymienione 15 artab krokoszu, żeby czynsz nie doznał żadnej strat, on sam zaś doznał kary, na jaką zasługuje.

$\mathrm{W}$ dokumencie tym znajdujemy wskazanie z jednej strony na potrzebę zwrócenia wyrządzonych szkód, a z drugiej na ukaranie sprawcy, co mogło przyjmować postać na przykład konfiskaty zwierzęcia. Zwięzłość

89 Tak dokument ten był interpretowany przez R. TAubenschlag, The Law of Greco-Roman Egypt in the Light of the Papyri, 332 B.C.-640 A.D.2, Warszawa 1955, s. 460 , przyp. 185. 
sformułowań nie pozwala jednak na potwierdzenie ani odrzucenie takiego rozwiązania. Brak w tym przypadku wskazywania na jakieś dodatkowe okoliczności zajścia (np. w postaci pobicia, jak we wcześniejszych petycjach) mógłby sugerować, że również ukaranie odnosiło się do przypadku szkód.

W związku z tym, że poza omówionymi dokumentami papirusy ptolemejskie dotyczące zagadnienia wypasu zawierały jedynie ogólne żądania zbadania sprawy ${ }^{90}$ czy otrzymania sprawiedliwości ${ }^{91}$, nie pomagają one w odtworzeniu prawnego charakteru odpowiedzialności za szkody wyrządzone przez zwierzęta.

$\mathrm{Na}$ podstawie przeanalizowanych dokumentów można jednak wskazać, że w okresie ptolemejskim pasterz był albo zobowiązany wyłącznie do zapłaty odszkodowania, albo też dotykała go konfiskata zwierzęcia. Nie było w nich natomiast mowy o wydaniu noksalnym. Wprawdzie właściciel mógł utracić zwierzę, ale nie przepadało ono na rzecz osoby poszkodowanej. Było ono natomiast konfiskowane przez państwo i sprzedawane przez urzędników. Z sumy uzyskanej w ten sposób były pokrywane roszczenia skarbu państwa, czy to w postaci czynszu, który mu się należał, czy też jakiejś kary, a resztę otrzymywał najprawdopodobniej właściciel czy dzierżawca zniszczonych upraw. Tak odpowiedzialność wyglądałaby przynajmniej w II w. p.n.e., na pewno w odniesieniu do ziemi królewskiej.

Taubenschlag, odwołując się do terminologii wyrastającej z prawa rzymskiego, dokonał w związku z tym rozróżnienia na odpowiedzialność cywilną oraz cywilno-karną, gdzie kryterium podziału miały stanowić według niego okoliczności, w których doszło do wyrządzenia

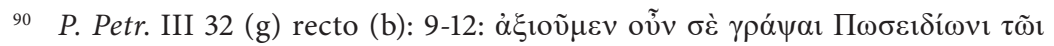

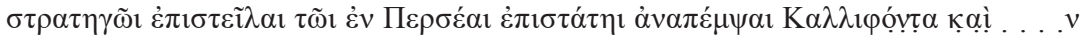

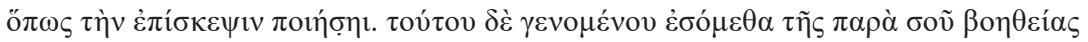

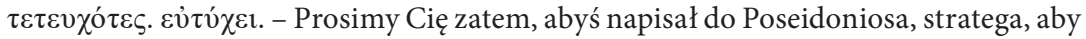
polecił epistatesowi z Persei, aby posłał Kallifona i ---, żeby on mógł zbadać sprawę; jeśli to zostanie uczynione, otrzymamy pomoc z Twoich rąk.

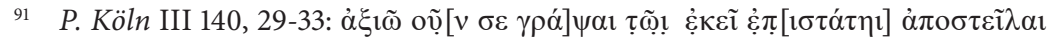

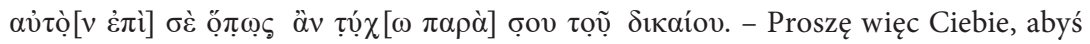
napisał do epistatesa, aby posłał go (Harchebisa) do Ciebie, tak żebym mógł otrzymać od Ciebie sprawiedliwość. 
szkody. W przypadku strat spowodowanych przez same zwierzęta ich właściciel miałby być zobowiązany jedynie do pokrycia szkód, natomiast w razie czynnego udziału człowieka, pan czy pasterz był odpowiedzialny za szkody, jak i podlegał karze (konfiskata zwierzęcia) ${ }^{92}$.

Przyjęte przez Taubenschlaga kryterium nie wydaje się jednak prawidłowe w świetle omówionych powyżej źródeł. Konfiskata zwierząt była bowiem przewidziana najprawdopodobniej zarówno w przypadku szkód wyrządzonych samodzielnie przez zwierzęta ( $P$. Hels. I 31), jak i przy udziale człowieka (P. Tebt. I 27). Również wyłączna odpowiedzialność odszkodowawcza miała miejsce w tych obydwu przypadkach. Należy zatem poszukać innych przyczyn zróżnicowania odpowiedzialności. Możliwości wydają się być dwie - albo uległa ona zmianie w czasie, albo też na jej charakter wpływ miała kategoria niszczonej ziemi.

Zajmijmy się najpierw drugim kryterium. Sankcja w postaci konfiskaty zwierzęcia poświadczona jest w okresie ptolemejskim wyraźnie wyłącznie w przypadku szkód powodowanych w ziemi królewskiej, której dotyczył P. Tebt. I $27^{93}$. Taubenschlag sugerował wprawdzie, że podobne uregulowania odnosiły się także do innych gruntów, powołując się w tym zakresie na $P$. Enteux. $75^{94}$, ale jak widzieliśmy, w nim nie było mowy o konfiskacie zwierząt, w związku z czym dokument ten nie jest argumentem za taką interpretacją. Także w P. Hels. I 31 i P. Heid. IX 422 petycję wnosili rolnicy królewscy uprawiający ziemię królewską ${ }^{95}$. Jednocześnie wyraźne poświadczenia wyłącznego żądania zapłaty odszkodowania znajdujemy jedynie w odniesieniu do gruntów należących do innych kategorii ziemi niż ziemia królewska - kleroi ${ }^{96} \mathrm{czy}_{\text {winnic }}{ }^{97}$.

92 R. Taubenschlag, The Law..., s. 460.

93 R. Taubenschlag, Die 'Actio de pastu'..., s. 567.

94 Ibidem, s. 568.

95 Nieco problematyczne jest jedynie ustalenie kategorii ziemi naruszonej w przypadku $P$. Ryl. II 69. W nim wnoszący petycję nie określili, jaka ziemia została zniszczona, wskazując jedynie, że byli rolnikami w służbie eklogistesa Achillesa. Wziąwszy jednak pod uwagę fakt, że eklogistes - „księgowy” był urzędnikiem nomu odpowiedzialnym za administrację podatkową, najprawdopodobniej uprawiali oni ziemię królewską. Por. o tym urzędniku np. A.B. Lloyd, op. cit., s. 404-405.

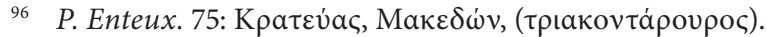

$97 \quad$ P. Enteux. 65. 
Tych rodzajów gruntów dotyczył również P. Petr. III 26, w którym wymienione były kleroi, winnice i ogrody, a więc zawsze ziemia znajdująca się w rękach prywatnych. Musimy jednak pamiętać, że w papirusach z III w. p.n.e., które pochodziły od rolników królewskich, albo w ogóle nie znajdujemy żądań (P. Heid. VII 394), albo były one ograniczone jedynie do wniosku o zbadanie sprawy (P. Petr. III 32 (g) recto (b)), co nie pozwala na ustalenie, jak kształtowała się odpowiedzialność za naruszenie ziemi królewskiej w pierwszym wieku panowania Lagidów i pewnie stwierdzić, że to kategoria gruntów decydowała o charakterze odpowiedzialności.

Jeżeli takie zróżnicowanie w oparciu o kategorię ziemi faktycznie by obowiązywało, to mogłoby ono wynikać z większego zainteresowania państwa stanem ziemi królewskiej niż innych jej rodzajów, takich jak ziemia świątynna, ziemia kleruchów, ziemia darowana czy ziemia prywatna, obejmująca przede wszystkim działki z winnicami czy też ogrodami ${ }^{98}$, co mogłoby być spowodowane wyższymi dochodami uzyskiwanymi przez państwo z tego pierwszego rodzaju gruntów. Do niedawna bowiem uznawano w doktrynie, że czynsz z niej płacony, przypadający skarbowi państwa, był istotnie wyższy niż podatki, które opłacano z innych kategorii ziemi ${ }^{99}$. Szkody w uprawach rosnących na niej w większym stopniu godziłyby zatem w interes państwa, co uzasadniałoby zaostrzenie odpowiedzialności. Jak wskazuje jednak w swoich najnowszych pracach Andrew Monson, o ile w okresie rzymskim rzeczywiście płacono zdecydowanie niższe podatki ze wszystkich kategorii ziemi prywatnej niż z ziemi publicznej, o tyle w okresie ptolemejskim najprawdopodobniej tylko obciążenia ziemi kleruchów były istotnie niższe, a te uiszczane z pozostałych były zbliżone do tych płaconych z gruntów królewskich ${ }^{100}$. Jeżeli tak było rzeczywiście, to kategoria ziemi niekoniecznie musiała mieć wpływ na odmienny zakres odpowiedzialności, chociaż nie można

98 J.G. Manning, Land and Power in Ptolemaic Egypt. The Structure of Land Tenure, Cambridge 2003, s. 89-94; S. REDEN von, op. cit., s. 88-89; A.B. LLOYD, op. cit., s. 404-405.

99 S. REDEN VON, op. cit., s. 88.

100 A. Monson, Land tenure and taxation from Ptolemaic to Roman Egypt, «Tyche» 25/2010, s. 62-63. 
wykluczyć, że większe zainteresowanie stanem gruntów królewskich spowodowane było nie tyle ewentualnymi wyższymi dochodami, ile silniejszą kontrolą państwa nad tą kategorią ziemi.

Być może jednak to nie względy podatkowe, a więc i nie kategoria ziemi, wpływały na zróżnicowanie odpowiedzialności, a zmiana w jej charakterze nastąpiła w czasie. To z III w. p.n.e. pochodzą bowiem wszystkie wyraźne świadectwa płacenia wyłącznie odszkodowania za szkody, a te przewidujące konfiskatę i sprzedaż zwierzęcia datowane są na II w. p.n.e. Mogłoby to sugerować, że w III w. p.n.e. we wszystkich przypadkach szkód, niezależnie od okoliczności ich wyrządzenia i kategorii ziemi, domagano się odszkodowania, po czym w II w. uległoby to zmianie.

Przyczyną zaostrzenia w II w. p.n.e. odpowiedzialności za szkody wyrządzane na skutek wypasu zwierząt mogłaby być trudna sytuacja polityczna w tym stuleciu spowodowana licznymi rewoltami ${ }^{101}$ i osłabieniem władzy. Zamieszki te przyczyniły się do pogorszenia stanu upraw, a co za tym idzie - zmniejszenia dochodów państwowych. Mogło to stanowić przyczynę zwiększenia odpowiedzialności za szkody w uprawach, zarówno w celu wzbogacenia skarbu państwa, jak i odstraszenia od tego rodzaju działań. Na podejmowanie różnego rodzaju kroków stanowiących wyraz troski o ziemię królewską w tym właśnie stuleciu wskazują także $\pi \rho o ́ \sigma \tau \alpha \gamma \mu \alpha \pi \varepsilon \rho \grave{i} \tilde{\eta} \varsigma \gamma \varepsilon \omega \rho \gamma \dot{i} \alpha \varsigma^{102}$ Ptolemeusza IV Filometora, dotyczące przymusowej uprawy roli, wydane po najeździe na Egipt Antiocha IV w 168 r. p.n.e. i rewolcie Dionysiosa Petosarapisa ze 165 r. p.n.e. W związku z brakiem chętnych do uprawy ziemi porzuconej w czasie tych wydarzeń władca nakładał na mieszkańców kraju obowiązek przymusowej dzierżawy ziemi królewskiej za zapłatą obniżonego

101 O rewoltach w II w. p.n.e. w Egipcie por. B. McGIng, Revolt Egyptian style: internal opposition to Ptolemaic rule, "Archiv für Papyrusforschung und verwandte Gebiete» 43/1997, s. 273-314.

102 SB XVI 12821=P. Gen. III 92=C. Ord. Ptol. 32 (165 p.n.e., nom arsinoicki). Tekst tego zarządzenia był wcześniej znany z cyrkularza zaadresowanego do Doriona (UPZ I 110=P. Paris 63=C. Ord. Ptol. All. 39) (164 p.n.e., Memfis). 
czynszu w naturze ${ }^{103}$. Miało to niewątpliwie spowodować zagospodarowanie ziemi królewskiej i uzyskanie z niej odpowiednich dochodów.

Podobne mogłyby być powody zaostrzenia odpowiedzialności za niszczenie pól na skutek nielegalnego wypasu. Niszczenie plonów przez zwierzęta interesowało nie tylko sąsiadów, lecz także króla, władcę ziemi i jej owoców, którego interes również był narażony na szwank w przypadku szkód w uprawach, powodujących niemożliwość zapłacenia należnych państwu obciążeń z ziemi. W związku z tym, że zwierzęta stawały się w takim przypadku narzędziem czynu na szkodę państwa i jego gospodarki ${ }^{104}$, wprowadzono konfiskatę stworzeń jako dotkliwą sankcję dla ich właścicieli czy pasterzy.

Niewykluczone zatem, że sankcja w postaci konfiskaty zwierząt była środkiem nadzwyczajnym, wprowadzonym w związku z kryzysem i trudną sytuacją ekonomiczną w Egipcie, mającym sprzyjać zwiększeniu dochodów państwa, i zapewniający odpowiednią troskę o ziemię królewską ${ }^{105}$.

Trudno jest określić rodowód odpowiedzialności w postaci konfiskaty zwierząt, z powodu jej wyjątkowości, jak i niewystarczającego materiału porównawczego. Nie wydaje się, żeby miała ona rodowód grecki, gdyż nie znajdujemy jej w żadnych źródłach greckich. Nie możemy jednak całkowicie wykluczyć, że zmiany, które widzimy w II w. p.n.e. i które ponownie są wyraźnie poświadczone w III i IV w. n.e. ${ }^{106}$, są wynikiem ewolucji prawa greckiego, która dokonałaby się pod wpływem warunków lokalnych i silniejszego niż w Grecji powiązania stanu ziemi z interesami państwa, albo też przejęciem egipskich rozwiązań funkcjonujących w tym zakresie przed podbojem. Właściwe dla Egiptu w każdym okresie jego istnienia było bowiem dążenie do ścisłego kontrolowania ziemi, z której płacono podatki, stanowiące podstawę utrzymania państwa. Jako że niszczenie upraw przez zwierzęta godziło w interes władcy,

103 J. MéLÈze Modrzejewski, Droit et justice dans le monde grec et hellénistique (JJurPap Supplement X), Warszawa 2011, s. 70-74.

104 J. MÉLÈze ModrzeJEwski, Ulpien et la nature..., s. 193.

105 Ibidem.

106 P. Oxy. XXXIV 2704 (292 n.e., Oksyrynchos), P. Cair. Isid. 78 (324 n.e., Karanis) i P. Mert. II 92 (324 n.e., Karanis). 
mogłoby to uzasadniać stosowanie surowszych konsekwencji niż te przewidziane $w$ innych prawach antycznych.

Czy faktycznie tradycji egipskiej znana była sankcja w postaci konfiskaty zwierząt, jest jednak praktycznie niemożliwe do stwierdzenia. Wprawdzie dysponujemy pewnymi tekstami z czasów faraońskich dotyczącymi zwierząt, ich hodowli, spisów, jak i w grobowcach przedstawiane były idylliczne sceny z życia pasterzy ${ }^{107}$, jednak jedynym źródłem egipskim, w którym znajdujemy wzmiankę o zjadaniu upraw przez zwierzęta, jest tekst znany jako Wymowny wieśniak, praca napisana w czasach Średniego Państwa, należąca do literatury moralizatorskiej ${ }^{108}$. Zdaje się ona sugerować, że także w Egipcie zasadą było pokrycie strat poprzez zapłatę odszkodowania, czemu ewentualnie mogło towarzyszyć wzięcie zwierzęcia w zastaw do czasu jego uiszczenia (Wymowny wieśniak 36-46) ${ }^{109}$.

Nie można w związku z tym wykluczyć, że postanowienie o konfiskacie było nadzwyczajną regulacją wydaną w czasach kryzysu, która następnie, ze względu na jej korzystny dla skarbu państwa charakter, nie została nigdy zniesiona. Rodowód i zakres zastosowania odpowiedzialności w postaci konfiskaty pozostaje natomiast kwestią otwartą.

Źródła papirusowe z okresu ptolemejskiego pokazują, że odpowiedzialność za szkody wyrządzone w uprawach przez zwierzęta, na skutek ich wypasu lub przepędzania, mogła wyglądać inaczej, niż przyzwyczaiły nas do tego prawa greckie czy rzymskie. Z jednej strony w źródłach mamy informację jedynie o zapłacie odszkodowania, bez jakiegokolwiek wskazania na funkcjonowanie w Egipcie odpowiedzialności noksalnej, z możliwością wydania zwierzęcia lub zapłatą odszkodowania. Z drugiej

107 Por. przede wszystkim W. Guglielmi, Reden, Rufe und Lieder aufaltägyptischen Darstellungen der Landwirtschaft, Viehzucht, des Fisch- und Vogelfangs vom Mittleren Reich bis zur Spätzeit, Bonn 1973, s. 95-143.

108 O tekście tym por. dokładnie jego najnowsze wydanie - R.B. PARKInson, The Tale of the Eloquent Peasant: A Reader's Commentary, Hamburg 2012.

109 Co do tego ostatniego punktu nie ma pełnej zgody wśród badaczy. Za taką możliwością opowiada się Shupak (N. SHUPAK, A new source for the study of the judiciary and law of ancient Egypt: 'The tale of the eloquent peasant', "Journal of Near Eastern Studies» 51/1992, s. 8-9), natomiast przeciwny jej jest Parkinson (R.B. PARKInson, op. cit., s. 48.). 
strony przewidują one konfiskatę zwierzęcia, na poczet skarbu państwa, co nieznane jest z żadnych innych starożytnych praw.

\section{ODPOWIEDZIALNOŚĆ ZA SZKODY WYRZĄDZONE PRZEZ ZWIERZĘTA W UPRAWACH W EGIPCIE PTOLEMEJSKIM}

\section{Streszczenie}

Szkody wywoływane przez zwierzęta były w Egipcie odwiecznym problemem. Dotyczy go wiele dokumentów papirusowych z okresu ptolemejskiego, w tym petycje, diagramma królewskie i zarządzenie. Wyłaniający się z nich obraz nie jest w pełni jasny. Wydaje się jednak, że w przeciwieństwie do tego, do czego przyzwyczaiło nas prawo rzymskie, sposób wyrządzenia szkód nie odgrywał większego znaczenia i nie wpływał na zakres odpowiedzialności. Nieistotne zatem było, czy straty zostały spowodowane przez same zwierzęta, czy też z inicjatywy pasterza. Nie znajdujemy w papirusach poświadczenia funkcjonowania w tym przypadku odpowiedzialności noksalnej z możliwością wydania zwierzęcia lub zapłatą odszkodowania, której doszukiwał się w Egipcie Modrzejewski, odwołując się do źródeł greckich. Odpowiedzialność za szkody zdaje się natomiast ulec zmianie na przestrzeni czasu. O ile w III w. p.n.e. domagano się zapłaty odszkodowania za zniszczone uprawy, o tyle w II w. p.n.e. źródła potwierdzają istnienie konfiskaty zwierząt. Zmiana ta mogła być spowodowana różnymi czynnikami, najprawdopodobniej problemami gospodarczymi w tym wieku.

\section{Liability in Ptolemaic Egypt for Damage to Crops Caused by Animals}

\section{Summary}

Damage caused by animals was a constant problem in Ptolemaic Egypt. There are numerous papyrus documents including petitions, royal decrees, and ordinances on this issue. The picture that emerges from them is not fully clear. However, it seems that, contrary to what 
Roman law has accustomed us to, the way the damage was caused was not very important and did not affect the scope of the liability. It was irrelevant whether the loss was caused by the animals themselves or whether it was instigated by the shepherd. There is no evidence in the papyri that in Egypt noxal liability was applicable for damage caused by animals, with the option of giving up the animal or paying compensation, as Modrzejewski would have it on the grounds of Greek sources. Liability for damage appears to have changed over time. While in the third century $\mathrm{BC}$ financial compensation was required for damaged crops, second-century BC sources say that the animals were confiscated. This change could have been caused by various factors, most likely the economic problems of those times.

Słowa kluczowe: nielegalny wypas; odpowiedzialność odszkodowawcza; konfiskata zwierząt; odpowiedzialność noksalna; papirusy, P. Tebt. I 27, P. Petr. III 26.

Keywords: illegal pasturage; compensation; confiscation of animals; noxal liability; papyri; P. Tebt. I 27; P. Petr. III 26.

\section{Literatura}

Ankum H., 'Actio de pauperie et actio legis Aquiliae' dans le droit romain classique, [w:] Studi in onore di Cesare Sanfilippo, II, Milano 1982, s. 13-59. Armoni C., Studien zur Verwaltung des Ptolemäischen Ägypten: Das Amt des Basilikos Grammateus, Paderborn 2012.

Ashton-Cross D.I.C., Liability in Roman law for damage caused by animals, «Cambridge Law Journal» 11/1953, s. 395-403.

Ashton-Cross D.I.C., Liability for animals in Roman law, "Cambridge Law Journal» 17.2/1959, s. 189-192.

Bauschatz J., Law and Enforcement in Ptolemaic Egypt, Cambridge 2013.

Berneker E., Zu einigen Prozessurkunden der Ptolemäerzeit, «Études de papyrologie» 2/1933, s. 59-69.

BieżuńsKa-MaŁowist I., Sytuacja społeczna niewolników w Egipcie Ptolemejskim, Warszawa 1976.

BuIs E.J., ¿Antecedentes de la 'actio de pauperie' en el derecho ático? La responsabilidad objetiva y los daños causados por animales domésticos en Atenas y 
Roma, http://www.edictum.com.ar/miWeb4/xix/Trabajos/BUIS\%20Emiliano.doc (dostęp: 20 sierpnia 2019 r.).

Calero Secall I., Las leyes creyentes y la responsabilidad noxal por los daños causados por animales y esclavos, «Florentina iliberritana» 25/2014, s. 31-47.

Calero Secall I., Plutarco y su interpretación de leyes griegas concernientes a la familia y propiedad, [w:] Nomos, Kosmos \& Dike in Plutarch, red. J. RIbeiro Ferreira, D.F. Leão, C.A. Martins de Jesus, Coimbra 2014, s. 53-66.

Di Bitonto A., Frammenti di petizioni del periodo tolemaico. Studio sul formulario, «Aegyptus» 56/1976, s. 109-143.

Di Bitonto A., Le petizioni al re: studio sul formulario, «Aegyptus» 47/1967, s. 5-57.

Finley M.I., Studies in Land and Credit in Ancient Athens, 500-200 B.C., The Horos Inscriptions ${ }^{2}$, Oxford 1985.

Gernet L., Aspects du droit athénien de l'esclavage, «Archives d'histoire du droit oriental. Revue internationale des droits de l'antiquité» 5/1950-1951, s. 159-178.

Giangrieco Pessi M.V., Ricerche sull' 'actio de pauperie' dalle XII Tavole ad Ulpiano, Napoli 1995.

Guglielmi W., Reden, Rufe und Lieder auf altägyptischen Darstellungen der Landwirtschaft, Viehzucht, des Fisch- und Vogelfangs vom Mittleren Reich bis zur Spätzeit, Bonn 1973.

HaAse R., Die Behandlung von Tierschäden in den Keilschriftrechten, «Revue internationale des droits de l'Antiquité» 14/1967, s. 11-65.

Hagedorn D., Bemerkungen zu Urkunden, «Zeitschrift für Papyrologie und Epigraphik»136/2001, s. 148-154.

Harrison A.R.W., The Law of Athens. The Family and Property, Oxford 1968. Haymann F., Textkritische Studien zum römischen Obligationenrecht III: Zur Haftung von Tierschaden ('actio de pauperie'), "Zeitschrift der Savigny-Stiftung für Rechtsgeschichte» 42/1921, s. 357-393.

Honoré T., Liability for animals: Ulpian and the compilers, [w:] Satura Roberto Feenstra: sexagesimum quintum annum aetatis complenti ab alumnis collegis amicis oblata, red. R. Feenstra, J.A. Ankum, J.E. Spruit, Fribourg 1985, s. 239-250.

JACKsON B.S., Liability for animals in Roman law: an historical sketch, «Cambridge Law Journal» 37.1/1978, s. 122-143.

Jager M., Reinsma M., Ein missverstandenes Gesetz aus ptolemäischer Zeit, [w:] Pap. Lugd. Bat. XIV, Leiden 1965, s. 114-115. 
Keenan J.G., Pastoralism in Roman Egypt, «The Bulletin of the American Society of Papyrologists» 26/1989, s. 175-200.

Kerr Wylie J., 'Actio de pauperie', [w:], Studi in onore di Salvatore Riccobono, IV, red. S. Riccobono, G. Baviera, Palermo 1936, s. 459-521.

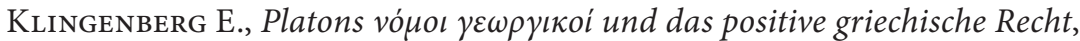
Berlin 1976.

Korus K., Trzcionkowski L., Plutarch. Żywoty równoległe II, Warszawa 2005. Lenger M.-Th., Le fragment de loi ptolémaïque P. Petrie III 26 (Bodl. Ms. Gr. class. d. 27 [P]), [w:] Studi in onore di Ugo Enrico Paoli, Firenze 1956, s. $459-476$.

Lewis N., Life in Egypt under Roman Ruler, Oxford 1983.

Lloyd A.B., The Ptolemaic period, [w:] The Oxford History of Ancient Egypt, red. I. SHAw, Oxford 2002, s. 404-405.

MacDowell D.M., The Law in Classical Athens, London 1986.

Manning J.G., Land and Power in Ptolemaic Egypt. The Structure of Land Tenure, Cambridge 2003.

Maykowska M., Platon. Prawa, Warszawa 1960.

McGing B., Revolt Egyptian style: internal opposition to Ptolemaic rule, «Archiv für Papyrusforschung und verwandte Gebiete» 43/1997, s. 273-314.

MéLÈze Modrzejewski J., Droit et justice dans le monde grec et hellénistique (JJurPap Supplement X), Warszawa 2011.

MéLÈze Modrzejewski J., Hommes libres et bêtes dans les droits antiques, [w:] Statut personnel et liens de famille dans les droits de l'Antiquité, Aldershot 1993, s. 75-102.

MéLÈze Modrzejewski J., Papyrologie et histoire des droits de l'Antiquité, [w:] École pratique des hautes études, 4 e section, Sciences historiques et philologiques. Annuaire 1973-1974, Paris 1974, s. 229-240.

MéLÈze Modrzejewski J., Ulpien et la nature des animaux, [w:] Droit impérial et traditions locales dans l'Égypte romaine, Aldershot 1990, s. 177-199.

Monson A., Land tenure and taxation from Ptolemaic to Roman Egypt, «Tyche» 25/2010, s. 55-71.

OAtes J.F., The Ptolemaic Basilikos Grammateus (BASP Supplements 8), Atlanta 1995.

Papadopoulou D., The administration of Egypt in Hellenistic times. The rise and fall of the oikonomos, "Anistorion Journal»12/2010, s. 1-4.

Parkinson R.B., The Tale of the Eloquent Peasant: A Reader's Commentary, Hamburg 2012. 
PŁodzień, S. The origin and competence of the $\pi \rho \alpha \dot{\alpha} \kappa \tau \rho \rho \xi \xi v \iota \kappa \tilde{\omega} v$, «The Journal of Juristic Papyrology» 5/1951, s. 217-227.

Polojac M., 'Actio de Pauperie' and Liability for Damage Caused by Animals in Roman Law, Belgrade 2003.

PoloJac M., 'Actio de pauperie': anthropomorphism and rationalism, «Fundamina»18.2/2012, s. 119-144.

Polojac M., L'actio de pauperie' ed altri mezzi processuali nel caso di daneggiamento provocato dall'animale nel diritto romano, «Ius Antiquum» 8/2001, s. 83-89 (http://www.dirittoestoria.it/iusantiquum/articles/N8Polojac.htm\#_ftn2).

Préaux C., L'économie royale des Lagides, Bruxelles 1939.

Reden von S., Money in Ptolemaic Egypt: from the Macedonian Conquest to the End of the Third Century BC, Cambridge 2010.

SAMuel A.E., The judicial competence of the oikonomos in the III century B.C., [w:] Atti dell'XI Congresso Internazionale di Papirologia, Milano, 2-8 settembre 1965, Milano 1966, s. 444-450.

Schnebel M., Die Landwirtschaft im hellenistischen Ägypten, München 1925.

SHupak N., A new source for the study of the judiciary and law of ancient Egypt: 'The tale of the eloquent peasant', "Journal of Near Eastern Studies» 51/1992, s. 1-18.

Taubenschlag R., Die 'Actio de pastu, de pauperie' und 'de arboribus caesis' im Rechte der Papyri, «Archív Orientální» 20/1952, s. 65-68 = R. TAUBENsCHLAG, 'Opera Minora', II, Warszawa 1959, s. 567-571.

Taubenschlag R., Selfhelp in Greco-Roman Egypt, [w:] R. Taubenschlag, 'Opera Minora', II, Warszawa 1959, s. 135-137.

Taubenschlag R., The Law of Greco-Roman Egypt in the Light of the Papyri, 332 B.C. -640 A.D. ${ }^{2}$, Warszawa 1955.

Todd S.C., The Shape of Athenian Law, Oxford 1993.

Watson A., The original meaning of 'pauperies', "Revue internationale des droits de l'Antiquité» 17/1970, s. 357-367.

Wolff H.J., The dikn $\beta \lambda \dot{\alpha} \beta \eta \varsigma$ in Demosthenes, Or. $L V$, «The American Journal of Philology» 64.3/1943, s. 316-324.

Vélissaropoulos-Karakostas J., Remarques sur la responsabilité civile en Grèce, «Cahiers du Centre Gustave Glotz» 9/1998, s. 71-82. 